\title{
Om grunnlovens medlemskapsprinsipp ved overføring av myndighet til internasjonale organisasjoner
}

\author{
AV TARJEI BEKKEDAL
}

Ph.d. Tarjei Bekkedal (f. 1977, cand.jur. 2001) er førsteamanuensis ved Senter for europarett, Nordisk institutt for sjørett. Artikkelen er en del av prosjektet "Europe in transition - Small states and Europe in an age of global shifts" (EUNOR), finansiert av Norges forskningsråd. E-post: tarjei.bekkedal@jus.uio.no.

\begin{abstract}
SAMMENDRAG I gjeldende konstitusjonell doktrine er det antatt at myndigheten til å binde Norge folkerettslig fritt kan overføres, i medhold av grunnloven $\$ 26$ andre ledd. Overføring av intern myndighet - lovgivende, dømmende og administrativ kompetanse krever i hovedregelen at Stortinget avgir samtykke i medhold av grunnloven $\$ 115$, noe som forutsetter norsk medlemskap. Artikkelen hevder at den tradisjonelle sondringen mellom folkerettslig virkning og «direkte virkning» er av underordnet betydning. Grunnlovens viktigste skillelinje er om Norge er medlem av den organisasjonen som det er snakk om å overføre myndighet til. Medlemskapsprinsippet i grunnloven $₫ 115$ gjelder også ved overføring av myndigheten til å binde Norge folkerettslig.
\end{abstract}

NØKKELORD EU, EØS, TTIP, grunnloven, myndighetsoverføring, suverenitet

SUMMARY The paper discusses the legal basis for Norway's accession to trade agreements, and the transfer of powers to international organizations. The Norwegian Constitution employs the concept of pooled sovereignty. A basic constitutional requirement for the transfer of powers is that Norway is a member of the organization to which powers are being delegated. The requirement of membership is rooted in the principle of democracy. 
The constitutional principles pose a challenge to the pragmatically constructed cooperation between Norway and the EU, which has taken the form of Norway being a «member without membership».

KEYWORDS EU, EEA, TTIP, constitution, transfer of powers, sovereignty

\section{Tema - overføring av myndighet til internasjonale organisasjoner ${ }^{1}$}

Iblant vil norsk deltakelse i internasjonalt samarbeid forutsette overføring av myndighet til internasjonale organisasjoner. Artikkelen drøfter konstitusjonelle krav og skranker for slik overføring, særlig betingelsen som kommer til uttrykk i grunnloven $\$ 115$, i så vel første som andre ledd: at Norge må være medlem av den organisasjonen det er aktuelt å overføre myndighet til. Dette omtaler artikkelen som medlemskapsprinsippet.

Da grunnloven ble endret i 1962, gjennom vedtakelsen av grunnloven $\$ 115$, var det for å lette adgangen til å delta i internasjonalt samarbeid, og vår grunnlov er liberal i så måte. ${ }^{2}$ Ønsker Norge å bli medlem av en internasjonal organisasjon, oppstiller grunnloven knapt materielle skranker av betydning. ${ }^{3}$ Den fastholder ikke at beslutninger som får virkning i eller for Norge, må fattes av nasjonale organer, men åpner i stedet for kollektivisering av suverenitet. Overføring av myndighet til en internasjonal organisasjon er forenlig med grunnloven, så fremt det skjer som ledd i en byttehandel - mot en andel i den større myndighetens utøvelse. Kravet om norsk deltakelse i organisasjonen sikrer at grunnleggende konstitusjonelle krav om demokrati og folkesuverenitet er oppfylt også der beslutninger løftes ut av den nasjonale sfære og opp på et internasjonalt plan. Samarbeid uten medlemskap vil utfordre og gripe inn i de samme prinsippene.

\section{Sentrale former for overføring av myndighet}

\subsection{Overføring av myndighet til å binde Norge folkerettslig}

De rettslige rammene for overføring av myndighet er komplekse. Før vi går løs på dem, er det en fordel å kjenne faktum - de sentrale former for overføring av myndighet.

1. Takk til Ivar Alvik, Mads Andenæs, Finn Arnesen, Hilde Ellingsen, Markus Jerkø, Jonas W. Myhre, Arnulf Tverberg, Eivind Smith og Stian Øby Johansen for kommentarer, innspill og kritikk. Som alltid ligger ansvaret for alle standpunkter og feil hos forfatteren alene.

2. Innst. S. nr. 100 (1961-62) s. 138.

3. Torkel Opsahl, «Selvstendighet og kongedømme», Tidsskrift for Rettsvitenskap 1969, s. 490-510 (s. 507): «All myndighet som er avledet av grunnloven kan internasjonaliseres, skritt for skritt, bare ikke selve den grunnlovgivende makt som alt det andre avhenger av.» 
Et klassisk eksempel på overføring av myndighet er Norges medlemskap i FN, som innebærer en viss overføring av myndighet til å fatte beslutninger som vil binde Norge folkerettslig. Et mer moderne og nokså annerledes eksempel er Norges tilslutning til Open Skies-avtalen. ${ }^{4}$ I utgangspunktet er dette en bilateral traktat mellom EU og USA, om fri luftfart. Her har Norge og Island sluttet seg til, via EU. Landene skal bli behandlet «as though they were Member States of the European Union». Avtalens system er at i spørsmål om traktatjustering og tvisteløsning mellom EU og USA representerer EU-kommisjonen Unionens og medlemsstatenes interesser. Gjennom en tilleggsavtale med EU er det fastslått at Kommisjonen på tilsvarende måte skal representere Norge. ${ }^{5}$ Slik representasjon vil kunne innebære en begrenset overføring av folkerettslig myndighet til EU, for verken EUs egne medlemsland eller Norge kan binde opp Kommisjonens kompetanse. Det er lett å tenke seg at denne samarbeidsformen kan tjene som modell og inspirasjon $i$ andre og viktigere forhold, for eksempel dersom EU og USA skulle bli enige om å etablere en transatlantisk handelsavtale (TTIP). ${ }^{6}$

\subsection{Overføring av lovgivende, administrativ eller dømmende myndighet}

Internasjonalt samarbeid kan også forutsette overføring av intern kompetanse, altså lovgivningsmyndighet, forvaltningsmyndighet eller dømmende myndighet. Et for Norge aktuelt utviklingstrekk, som tjente som utgangspunkt for Eirik Holmøyviks viktige bidrag til den rettslige diskursen på området, er fremveksten av overnasjonale forvaltningsorganer i EU. Norsk tilslutning vil kreve overføring av myndighet til å fatte administrative vedtak, på et saklig begrenset område. Disse vedtakene får direkte virkning i intern norsk rett, overfor nasjonale forvaltningsmyndigheter så vel som private rettssubjekter, uten at noen ytterligere gjennomføringsakt fra norske myndigheters side er nødvendig. Holmøyviks varsku i denne sammenheng er at grunnlovens skranker mot overføring av intern myndighet blir tatt for lett på. ${ }^{7}$ Samtidig er det ingen tvil om at dens begrensninger er reelle, og volder betydelige praktiske og politiske utfordringer. For eksempel ble grunnloven ansett å stå i veien for å overføre myndighet til EUs nye finanstilsyn, selv om det synes å ha vært bred politisk oppslutning om hensiktsmessigheten av norsk tilslutning. ${ }^{8}$

4. Air Transport Agreement, Official Journal L 134 25.5.2007 s. 4.

5. Official Journal L 28329.10 .2011 s. 1-24, se særlig tilleggsavtalens artikkel 3 og 4 .

6. Om mulige modeller for norsk tilknytning, se, Transatlantisk frihandel og Norge, NUPI-rapport nr. 7/2014, kapittel 2.

7. Eirik Holmøyvik, «Grunnlova § 93 og læra om 'lite inngripende' myndigheitsoverføring i lys av nyare konstitusjonell praksis», Lov og Rett 2011, s. 447-471. 
Et annet fenomen med stor utbredelse internasjonalt er etablering av bilaterale handels- og investeringsavtaler med voldgiftsklausuler. Klausulene innebærer at tvister om forståelsen av traktatene skal løses av internasjonale voldgiftstribunaler. Investorer har individuell adgang til å anlegge søksmål dersom de mener at deres traktatfestede rettigheter er krenket, og tribunalenes avgjørelser skal ha direkte virkning i traktatstatene. Justisdepartementets lovavdeling har tidligere funnet det tvilsomt om overføring av dømmende myndighet er forenlig med grunnloven. ${ }^{9}$ Norge har derfor ikke inngått slike avtaler siden 1995. Samtidig som denne praksisen er blitt kritisert for å være for restriktiv, illustrerer den at grunnloven kan oppstille skranker mot internasjonalt samarbeid som det kan være vanskelig å komme rundt. ${ }^{10}$

\subsection{Avtaler som reelt, men ikke formelt overfører myndighet}

Av rettslige og politiske grunner er norsk deltakelse i internasjonalt samarbeid i stor grad innrettet slik at det rent formelt ikke finner sted overføring av myndighet overhodet. Norges sentrale avtaler med EU, som EØS-avtalen og Schengen-avtalen, er konstruert slik at de (i all hovedsak) verken overfører kompetanse til å binde Norge folkerettslig eller intern kompetanse. Når EU vedtar ny lovgivning, må denne først innlemmes i EØS-avtalen slik at den blir folkerettslig bindende for Norge. ${ }^{11}$ Deretter må Norge vedta nasjonal lovgivning som gjenspeiler de folkerettslige forpliktelsene som oppstår gjennom avtalejusteringen, slik at de får effekt i vår interne rettsorden. ${ }^{12}$ Konstruksjonen forutsetter altså en løpende tilpasning, hvor det er to ledd fra vedtakelse av en ny rettsakt i EU til gjennomføring i norsk rett. Formelt ligger begge disse i Norges hender, men skal samarbeidet bestå, har Norge i realiteten ikke andre muligheter enn å føye seg. ${ }^{13}$ I Europautredningen er den siste erkjennelsen uttrykt slik: ${ }^{14}$

8. Justisdepartementets lovavdeling har antatt at norsk tilslutning i noen henseende vil innebære en så vidt omfattende overføring av forvaltningsmyndighet at § 115 -vedtak vil være nødvendig. Problemet i så måte er at bestemmelsens første ledd bare åpner for å overføre myndighet til organisasjoner Norge er medlem av. Derfor er det forhandlet frem en løsning med EU om at Norge i stedet overfører myndighet til EFTA-pilaren ved ESA (Brussels, 14 October 2014 14178/1/14 Rev 1). Lovavdelingens standpunkter fremgår i et sett av ulike vurderinger: JDLOV-2010-10039A; JDLOV-201010039B; JDLOV-2010-10039C.

9. JDLOV-1997-5405 Voldgiftsklausuler i bilaterale investeringsbeskyttelsesavtaler. Mindre restriktivt, notat 7.12.2006 Bilaterale investeringsavtaler - konstitusjonelle sporsmål.

10. Are Brautaset, «Behov for bilaterale investeringsavtaler», Lov og Rett 2012, s. 385-386.

11. Dette skjer gjennom avgjørelse i EØS-komitéen, jf. EØS-avtalen artikkel 102. Rent formelt er ingen myndighet overført til EØS-komitéen. Det følger implisitt av at vedtak i komitéen krever enstemmighet, jf. EØS-avtalen artikkel 93.2.

12. EØS-avtalen artikkel 7.

13. For en analyse av EØS-avtalens reelle effekter, se for eksempel Benedikte Moltumyr Høgberg, «EØSrettens betydning for norsk statsrett», Jussens Venner 2008, s. 159-178.

14. NOU 2012: 2 Europautredningen, s. 232. 
Norges avtaler med EU innebærer i realiteten en omfattende overføring av myndighet fra nasjonalt nivå til EU-nivå. Dette skjer gjennom konstruksjoner som skal sikre at Norge selv fortsatt har formell kontroll, og kanaliseres formelt gjennom organisasjoner som Norge er medlem av. Men i realiteten er det tale om overføring av myndighet til EU. Først og fremst gjelder det lovgivende myndighet, men også i noen grad utøvende og dømmende.

Det er grunn til å understreke at det å inngå forpliktende traktater, også om de materielt er svært omfattende, normalt ikke i seg selv reiser konstitusjonelle problemer, så lenge traktatene er endelige. Anvender man sin frihet til å inngå omfattende kontrakter, utøver man suverenitet, man overfører den ikke. Problemet med EØS og Schengen er imidlertid at selv om hver enkelt av de løpende traktatjusteringer er en ny og i formell forstand endelig avtale, så hviler rammeverket som sådant på en klar forutsetning om at Norge ikke kan gjøre bruk av sin frihet til å si nei mens samarbeidet løper. Det er dette, og ikke avtalenes omfang i seg selv, som skaper gapet mellom formaliteter og realiteter.

\section{Gjeldende lære - om dagens konstitusjonelle praksis}

I artikkelen forutsetter jeg at vi står overfor en traktatslutning som krever Stortingets godkjennelse. I grunnloven finnes tre ulike prosedyrer for dette, med ulik terskel. Enklest er godkjenning i form av alminnelig flertallsbeslutning, jf. grunnloven $\$ 26$ andre ledd. For de mer inngripende traktater kreves vedtak med kvalifisert $3 / 4$ flertall, jf. grunnloven $\$ 115$ første ledd. I ytterste fall er det nødvendig med grunnlovsendring, jf. grunnloven $\$ 121$, dersom ingen av de to øvrige fremgangsmåter står åpne. Grunnloven $\$ 121$ skal jeg ikke drøfte i det videre.

Grunnloven $\$ 115$ er lesten som dagens konstitusjonelle praksis om valg av hjemmelsgrunnlag og prosedyre er bygget over. Bestemmelsen lyder slik:

For å sikre den internasjonale fred og sikkerhet eller fremme internasjonal rettsorden og samarbeid kan Stortinget med tre fjerdedels flertall samtykke i at en internasjonal sammenslutning som Norge er tilsluttet eller slutter seg til, på et saklig begrenset område skal ha rett til å utøve beføyelser som etter denne Grunnlov ellers tilligger statens myndigheter, dog ikke beføyelse til å forandre denne Grunnlov. Når Stortinget skal gi sitt samtykke, bør, som ved behandling av grunnlovsforslag, minst to tredjedeler av dets medlemmer være til stede.

Bestemmelsene i denne paragraf gjelder ikke ved deltagelse i en internasjonal sammenslutning hvis beslutninger bare har rent folkerettslig virkning for Norge. 
Tradisjonelt er oppbygningen av grunnloven $₫ 115$ - dens to ledd - blitt tatt til inntekt for en skarp konstitusjonell sondring mellom traktatforpliktelser som skaper direkte internrettslig virkning, og traktatforpliktelser som «kun» innebærer folkerettslige virkninger. ${ }^{15}$ Anvender vi dette utgangspunktet på det første av typetilfellene som ble beskrevet foran i avsnitt 2, vil man altså legge til grunn at overføring av myndighet til å binde Norge folkerettslig - utenrikskompetansen - er dekket av grunnloven $\$ 115$ andre ledd, som gjør unntak fra kravene i den samme bestemmelsens første ledd. Gjeldende lære prediker at Stortinget i slike tilfeller kan nøye seg med alminnelig flertallsvedtak, jf. grunnloven $\$ 26$ andre ledd. Til forskjell fra dette må Stortingets samtykke til overføring av intern kompetanse altså lovgivende, administrativ eller dømmende myndighet - $\mathrm{i}$ hovedregelen avgis i medhold av grunnloven $\$ 115$ første ledd (om vi foreløpig ser bort fra den snevre, men praktisk viktige modifikasjonen som følger av læren om «lite inngripende» myndighetsoverføring). I slike tilfeller må Stortinget fatte sin beslutning med kvalifisert $3 / 4$ flertall. Samtidig er det i dette henseende alminnelig akseptert at Norge må være medlem av den organisasjonen som myndigheten blir overført til.

Når det gjelder det tredje eksemplet i avsnitt 2, avtaler konstruert slik som EØS og Schengen, legger dagens praksis avgjørende vekt på hvordan avtalene er konstruert rent formelt. Da Norge sluttet seg til EØS-avtalen, ble det for eksempel antatt at det ene, avgjørende kriterium for å trekke grensen mellom grunnloven $\$ 26$ og $\$ 115$ var «direkte virkning». ${ }^{16}$ Regjeringen la til grunn at de folkerettslige forpliktelsenes omfang og realitetseffekter i utgangspunktet ikke kunne påvirke den konstitusjonelle vurderingen. Den klare hovedregelen er derfor at godkjenning i form av alminnelig flertallsvedtak, jf. grunnloven $\$ 26$ andre ledd, er tilstrekkelig for disse konstruksjonenes vedkommende.

Artikkelen foretar ingen detaljert analyse av Lovavdelingens praksis, ${ }^{17}$ men nøyer seg med å henvise til sammenfatningen av rettstilstanden slik den kom til uttrykk i stortingsproposisjonen om Norges tilslutning til Schengen-samarbeidet. Her heter det: ${ }^{18}$

15. Slik for eksempel Fredrik Sejersted i Fredrik Sejersted \& Erik Boe, Schengen og Grunnloven, Oslo 1999, s. 17. Se også Arnulf Tverberg, Staten - herre i eget hus? Grunnloven og verden rundt oss, Lovdata.no 2014.

16. St.prp. nr. 100 (1991-92) EØS, s. 337-338. I proposisjonen er dette forankret gjennom en henvisning til en uttalelse fra Stortingets utenriks- og konstitusjonskomité, inntatt som vedlegg til Innst. S. nr. 149 og 150 (1962-63) Felles luftfartssystem for NATO, s. 334. Denne uttalelsen drøfter imidlertid ikke det prinsipielle skillet mellom grunnloven $\S 26$ og $\S 115$. Den peker bare på det opplagte, at grunnloven $\S 115$ gir hjemmel for å overføre myndighet med direkte virkning i intern rett.

17. En dokumentasjon av praksis er gitt i JDLOV-2013-6526, Nye prosedyreregler for offentlig stotte, punkt 3.1.

18. St.prp. nr. 50 (1998-99) Schengen, s. 35. Originaltekstens henvisninger til grunnloven § 93 er her, og ellers hvor det er aktuelt, erstattet med en henvisning til grunnloven $\S 115$. Opplistingen i proposisjonen er temmelig grovkornet, for særlig grunnloven $§ 75$ oppstiller langt flere kompetanser, og disse er av stor betydning, som for eksempel beskatnings- og bevilgningsmyndigheten. 
Grovt sett kan man si at Grunnloven omhandler fem forskjellige former for myndighet:

1. myndighet til å endre Grunnloven,

2. lovgivningsmyndighet,

3. domsmyndighet,

4. forvaltningsmyndighet (herunder myndighet til å utøve tvang), og

5. myndighet til å forplikte Norge folkerettslig.

Myndighet som nevnt i nr 1, altså myndighet til å endre Grunnloven, kan ikke overføres ut av riket, verken etter $\$ 26$ eller etter $\$ 115$.

De tre neste formene for myndighet - lovgivningsmyndighet, domsmyndighet og forvaltningsmyndighet - har det til felles at utøvelse av dem kan få 'direkte virkning' i forhold til borgerne. Overføring av slik myndighet ut av riket krever i utgangspunktet vedtak etter $\$ 115$. Er myndighetsoverføringen ikke av 'inngripende art', er det likevel antatt at vedtak etter $₫ 26$ annet ledd er tilstrekkelig (jf Fleischer, 'Grunnlovens $₫ 93$ ' i Jussens Venner serie Y (1963) s 89).

Utøvelse av den siste formen for myndighet, altså myndighet til å forplikte Norge folkerettslig, får ikke 'direkte virkning' i forhold til borgerne. Overføring av slik myndighet ut av riket krever ikke - iallfall i utgangspunktet ikke - vedtak etter $\$ 115$. Myndighet til å forplikte Norge folkerettslig kan derimot etter sikker praksis normalt overføres etter reglene i $\$ 26$.

Skillet mellom direkte virkning og folkerettslig virkning har altså betydning for om det i utgangspunktet er $\$ 26$ eller $\$ 115$ som må brukes for å overføre myndighet ut av riket.

Det siterte viser hvordan gjeldende lære tillegger sondringen mellom folkerettslig og «direkte virkning» nærmest avgjørende betydning for valg av hjemmelsgrunnlag og prosedyre når Stortinget skal godkjenne traktater som innebærer overføring av myndighet.

\section{Tesen om medlemskapsprinsippet og dens grunnlag}

Artikkelen utfordrer gjeldende lære, slik denne er utlagt foran. Tesen lyder slik: Når det gjelder overføring av myndighet, går grunnlovens viktigste skillelinje ikke mellom myndighet av henholdsvis folkerettslig eller internrettslig karakter. Det avgjørende er om Norge er medlem av organisasjonen som myndigheten blir overført til.

Begrunnelsen for tesen er tredelt. For det første hviler dagens praksis på en overdreven skarp sondring mellom hhv. første og andre ledd i grunnloven $\$ 115$. Utenrikskompetansen - adgangen til å binde Norge folkerettslig - ligger til Kongen, jf. grunnloven $\$ 26$ første ledd. Derfor er utenrikskompetansen utvilsomt en 
beføyelse som «etter denne Grunnlov [...] tilligger statens myndigheter», jf. grunnloven $\$ 115$ første ledd. At denne kompetansen ikke fritt kan overføres, var noe av bakgrunnen for at grunnloven $\$ 115 \mathrm{i}$ sin tid ble vedtatt. I diskusjonen om norsk medlemskap i Det europeiske fellesskap, med tilhørende overføring av myndighet, konstaterte Johs. Andenæs at innmelding ville krenke grunnloven $₫ 26 .{ }^{19}$ Både ordlyden og tilblivelseshistorien gjør det lite tvilsomt at grunnloven $₫ 115$ første ledd også omfatter traktatmyndigheten, overføring av kompetansen til å binde Norge folkerettslig.

For det andre: Samtidig som dagens konstitusjonelle praksis synes å hvile på en overdreven sondring mellom de to leddene i grunnloven $₫ 115$ når det gjelder hhv. overføring av intern kompetanse og utenrikskompetanse - overser den på samme tid prinsippet som gjennomsyrer bestemmelsen. Første ledd snakker om overføring av myndighet til en «sammenslutning som Norge er tilsluttet». I andre ledd heter det at de skjerpede kravene i bestemmelsens første ledd skal ikke gjelde ved «deltagelse $i$ en internasjonal sammenslutning hvis beslutninger bare har rent folkerettslig virkning for Norge» (min utheving). Medlemskapsprinsippet kommer dermed til uttrykk også i andre ledd. Om man leser andre ledd som et en bloc unntak for enhver forpliktelse av folkerettslige karakter, ser man bort fra denne viktige forutsetningen.

For det tredje er dagens formalistiske sondring mellom folkerettslig og internrettslig direkte virkning vanskelig å begrunne både prinsipielt og rettspolitisk. Som vi skal se, bygger skillet på gamle betraktninger om statssuverenitet, som ble ansett for å være foreldet allerede før grunnloven $\$ 115$ ble vedtatt - og som det for øvrig er vanskelig å finne rettskildemessig belegg for. Det idéhistoriske grunnlaget for den betydelige veksten i internasjonalt samarbeid etter andre verdenskrig er at statenes uavhengighet kan bestå samtidig som deres folk kollektiviserer sin folkesuverenitet gjennom medlemskapsorganisasjoner.

\section{Tilnærmingen videre}

Formålet med avsnitt 6 nedenfor er å belegge følgende påstand: Motsatt av premisset som ligger til grunn for dagens konstitusjonelle praksis, kan utenrikskompetansen i grunnloven $\$ 26$ i utgangspunktet ikke delegeres.

Formålet med avsnitt 7 nedenfor er å belegge følgende påstand: Vedtakelsen av grunnloven $\$ 115$ tjener til å slå fast at utenrikskompetanse likevel kan overføres til en organisasjon som Norge er medlem av.

19. Andenæs, Dok. 3 (1961-62) s. 16. «Det foreligger altså her en overføring av den traktatmyndighet som etter grunnlovens § 26 ligger hos Kongen. Heller ikke denne myndighetsoverføring lar seg forene med grunnloven slik den nå lyder.» 
Drøftelsene i artikkelens avsnitt 6 og 7 åpner for å se konstruksjoner som EØS og Schengen i et nytt lys. Siden disse avtalene er konstruert slik at de bare overfører myndighet reelt, men ikke formelt, omgår de grunnlovens begrensninger. I teori og praksis synes det å bli antatt at man på et eller annet tidspunkt må skjære gjennom fra formalitet til realitet, i hvert fall i prinsippet - og at det nok går en grense for hvor omfattende avtaler av denne typen Stortinget kan godkjenne gjennom alminnelig flertallsvedtak. ${ }^{20}$ Problemet er at kriterier for eventuell gjennomskjæring både er vanskelige å utforme og å praktisere. Avsnitt 8 viser at medlemskapsprinsippet - forstått som et demokratiprinsipp - gir grunnlag for en mer presis og kritisk konstitusjonell analyse av «medlem-uten-medlemskap-konstruksjoner» enn de spede forsøkene på å oppstille gjennomskjæringsregler som en ser i teori og praksis.

Samlet viser artikkelen at dagens konstitusjonelle doktrine setter medlemskapsprinsippet - slik dette følger av grunnlovens ordlyd samt av forarbeider og teori på tidspunktet da grunnloven $₫ 115$ ble vedtatt - til side. Artikkelen tar ikke dermed også stilling til om grunnloven er krenket. Det siste spørsmålet vil særlig bero på hvilken rettskildemessig vekt man tillegger Lovavdelingens etterfølgende praksis. Jeg avgrenser mot å behandle dette nærmere, og nøyer meg med to observasjoner. For det første er det neppe grunn til å tillegge Lovavdelingens grunnlovspraksis samme tyngde som for eksempel Høyesteretts praksis. Lovavdelingens praksis er utpreget byråkratskapt - innoverskuende og selvrefererende. Standpunkter blir ikke til under samme form for meningsbrytning og kontinuerlig problematisering som domstolenes avgjørelser. Derfor kan selv en omfangsrik praksis bero på hvilket standpunkt et fåtall embetsmenn en gang for lenge siden slo inn på. For det andre er det tvilsomt hvilken tyngde Lovavdelingens praksis kan avlede av at Stortinget har innrettet seg etter vurderingene. Stortinget synes å respektere Lovavdelingens standpunkter mer enn å slutte seg til dem (eller å utfordre dem). Vekten av Lovavdelingens praksis må i all hovedsak bero på om vurderingene er å anse som rettslig korrekte.

\section{Utgangspunktet: Utenrikskompetansen kan ikke delegeres 6.1 Grunnloven $\S 26$ - traktatkompetanse og folkesuverenitet}

Grunnloven $₫ 26$ første ledd legger traktatkompetansen til Kongen - i moderne språkbruk til Regjeringen. Bestemmelsens andre ledd kom til i 1931, og krever Stortingets samtykke dersom en traktat er av særlig stor viktighet, eller dersom

20. At gjeldende praksis suppleres av en gjennomskjæringsregel, synes det å være allmenn aksept for, se for eksempel Sejersted (1999) s. 21. Sammenhold St.prp. nr. 50 (1998-99) Schengen, omtalt nærmere i avsnitt 8 nedenfor, jf. for eksempel JDLOV-1997-5405 Voldgiftsklausuler i bilaterale investeringsbeskyttelsesavtaler, pkt. 4.2 jf. pkt. 7.3.2 og 7.3.3. 
iverksettelsen av en traktat nødvendiggjør en ny lov eller stortingsbeslutning. Forutsetningen om Stortingets samtykke ble ansett å gjelde også før andre ledd ble vedtatt. ${ }^{21}$ Den ble utledet direkte av grunnlovens øvrige bestemmelser og system særlig fra prinsippet om maktfordeling og fra prinsippet om at folket er landets øverste myndighet. Kongen kan ikke anvende traktatmyndigheten til å omgå Stortingets lovgiverkompetanse, eller til å sette Stortinget i en tvangssituasjon.

Grunnloven $₫ 26$ andre ledd er det eneste skrevne uttrykk for et dualistisk system i vår grunnlov. For denne fremstillingens vedkommende forutsetter jeg hele veien at Stortingets samtykke til en traktatinngåelse både er påkrevet og foreligger. Dermed oppstår ingen spørsmål om forholdet mellom regjering og storting. Likevel er grunnloven $\$ 26$ andre ledd av stor betydning fordi det uttrykker forbindelsen til folkesuverenitetsprinsippet. Dette prinsippets fanebestemmelse, grunnloven $₫ 49$, refererer etter sin ordlyd bare til lovgivningsmyndighet. Grunnloven $\$ 26$ andre ledd innebærer at også traktatkompetansen er underkastet folkesuverenitetsprinsippets virkeområde, noe som utvider rekkevidden til grunnloven $₫ 49$ tilsvarende. Dette skaper en parallellitet mellom lovgivende kompetanse og kompetansen til å stifte folkerettslige forpliktelser, som er i samsvar med den tradisjonelle forståelsen av suverenitet: Den suverene stat er den høyeste rettsmakt i forhold til sine egne borgere, og den «inngår selv sine avtaler og blir ikke bundet folkerettslig av det andre beslutter». ${ }^{22}$ Parallelliteten er et argument i favør av å likestille overføring av utenrikskompetanse og overføring av alminnelig lovgivningskompetanse, slik at begge deler må skje som ledd i kollektivisering av suverenitet og vil betinge «andel i myndighetens utøvelse» - hvilket i hovedregelen forutsetter norsk medlemskap. ${ }^{23}$

\subsection{Paradokset som gjeldende rett hviler på}

Den gjeldende konstitusjonelle lære prediker ikke parallellitet slik som beskrevet $\mathrm{i}$ avsnittet foran, men forutsetter tvert imot en diametralt ulik tilnærming når det gjelder overføring av intern kompetanse og utenrikskompetanse. Når det gjelder myndigheten som følger av grunnloven $\$ \$ 3,75$ og 88 , er det vanlig, uten videre, å fastslå at slik intern kompetanse må utøves av norske myndighetsorganer. Dette vil i hovedregelen være til hinder for å overføre kompetansen til organer utenfor riket - med mindre Stortinget faller tilbake på grunnloven $\$ 115$ første ledd. Ifølge

21. Se Frede Castberg, Norges statsforfatning II, annen utgave, Oslo 1947, s. 154. Kodifiseringens hovedformål var å gi begrensningen et skriftlig uttrykk, fordi man antok at dette utad ville begrense Kongens legitimasjon tilsvarende.

22. Carl August Fleischer, Folkerett, 8. utg. Oslo 2005, s. 68.

23. Formuleringen er lånt fra Opsahl, Dok. 10 (1966-67) s. 29. 
Arnulf Tverberg er dette utgangspunktet så «enkelt, og så selvsagt at det ikke fremgår direkte av grunnloven selv, men bare er forutsatt: I Norge er det norske statsorganer som utøver myndighet overfor personer og foretak. Den norske stat er herre i eget hus.» ${ }^{24}$

Den ulovfestede læren om «lite inngripende» myndighetsoverføring utgjør et snevert unntak fra hovedregelen om at intern kompetanse ikke gjennom alminnelig flertallsvedtak kan overføres til organisasjoner utenfor riket. ${ }^{25}$ Denne lærens eksistens markerer, og hviler på, en oppfatning om at bestemmelsene som læren tjener til å modifisere, egentlig er for ikke-delegasjonsprinsipper å regne. Læren om «lite inngripende» myndighetsoverføring følger altså ikke som konsekvens av at de berørte kompetansebestemmelsene i grunnloven blir tolket for å avdekke hvor langt de i seg selv åpner for å overføre myndighet. I stedet markerer læren at man $i k k e$ trenger å tolke de respektive bestemmelsene, fordi man kan ta for gitt at enhver overføring av intern myndighet uten videre vil bli ansett for å berøre norsk suverenitet - delegasjon vil gripe inn i det selvfølgelige utgangspunktet om at «staten er herre i eget hus», om man anvender Tverbergs mer diffuse retorikk. Når det gjelder intern kompetanse, synes ikke-delegasjonsprinsippet dermed å være utledet av selvstendighetskravet i grunnloven $\$ 1 .{ }^{26} \mathrm{I}$ forlengelsen fremstår læren om «lite inngripende» myndighetsoverføring som en rettslig standard, utviklet med selvstendighetskravet som lest.

Paradokset er at dagens konstitusjonelle doktrine også synes å legge til grunn at den siste av grunnlovens kompetanser - utenrikskompetansen, som etter grunnloven $\$ 26$ er lagt til Kongen - kan delegeres til organisasjoner utenfor riket gjennom alminnelig flertallsvedtak, jf. grunnloven $\$ 26$ andre ledd. ${ }^{27}$ Også det siste standpunktet ser ut til å bli betraktet som så opplagt at nærmere drøftelse er overflødig, men der slutter likheten. Det er vanskelig å akseptere at de diametralt ulike standpunktene når det gjelder overføring av intern kompetanse og overføring av utenrikskompetanse, kan være korrekte på samme tid. Hvis spørsmålet om myndighetsoverføring knytter an til oppfatninger om suverenitet, vil man i utgangspunktet forvente en stor grad av parallellitet, jf. avsnitt 6.1 foran.

24. Arnulf Tverberg, Staten - herre i eget hus? Grunnloven og verden rundt oss, Lovdata.no (utheving i original). Tilsvarende er lagt til grunn i Lovavdelingens praksis, se f.eks. JDLOV-1997-5405, pkt. 4.2 og JDLOV2010-10039C pkt. 3.3, og av Holmøyvik (2011), s. 448-449.

25. Om læren, se Fredrik Lied Lilleby, Grunnloven $\S 93$ og unntaket for «lite inngripende» myndighetsoverføring, Perspektiv 03/10 (Stortingets utredningsseksjon); Holmøyvik 2011.

26. Slik f.eks. St.prp. nr. 100 (1991-92) EØS, s. 336.

27. St.prp. nr. 50 (1998-99) s. 34 tar forbehold om at det ikke må dreie seg om overføring av «myndighet $\mathrm{i}$ alt for omfattende grad» - et kriterium som ligger i den motsatte ytterkant av «lite inngripende», og som neppe er rettslig operasjonaliserbart. 


\subsection{Om forholdet til grunnloven $\$ 1$}

\subsubsection{Utgangspunktet: Dogmet om statens absolutte handlefrihet}

Den gjeldende holdning i norsk rett er altså at det går et avgjørende skille mellom forpliktelser som er av rent folkerettslig karakter, og det å overføre intern myndighet. Som Sejersted påpeker, er «[s]ondringen mellom 'vanlig' folkerett og direkte virkning [...] knyttet til det klassiske synet på nasjonalstatenes 'suverenitet' ». ${ }^{28} \mathrm{Om}$ vi leter etter opphavet til en slik ytterliggående form for dualisme, vil vi oppdage at det er hentet fra gammel tysk doktrine. ${ }^{29}$ Et avgjørende kriterium for om en stat er selvstendig, var i henhold til denne doktrinen om statens handlefrihet kun er begrenset ved folkerettslige bånd, eller også ved statsrettslige bånd. ${ }^{30}$

Utgangspunktet for den eldre doktrinen var et dogmatisk syn på statens suverenitet, som et aksiomatisk utgangspunkt, og som noe ukrenkelig og rettslig urørlig - uimottakelig for enhver begrensning. ${ }^{31}$ Med et slikt utgangspunkt oppstår behovet for å forklare og rasjonalisere hvorfor begrensningene som følger av inngåtte traktater, ikke er i strid med dogmet. Doktrinens svar var at begrensninger som følger av traktater, er selvpålagte og springer ut av statenes egen vilje. Dette kan fremstå som en plausibel tilnærming der stater inngår traktater som er statiske og endelige, slik det var vanlig i eldre tider. Statene kan her sammenliknes med enkeltpersoner. Når man inngår en avtale, oppgir man ikke sin autonomi, man utøver den. Det er tilfelle selv om avtalen fører med seg forpliktelser. Derimot er doktrinen vanskelig å opprettholde ved overføring av utenrikskompetanse, for eksempel til en annen stat, eller til en internasjonal organisasjon med autonome beslutningsorganer. Da må man i så fall ty til temmelig drøye konstruksjoner for å døyve realitetene. Med sikte på unionen mellom Norge og Sverige hevdet for eksempel Gjelsvik at en stat A er suveren selv om den lar stat B bestemme i sine utenrikspolitiske anliggender. Stat A har bundet seg ved egen vilje «men nyttar ein annen stat til organ for denne viljen». ${ }^{32}$

28. Sejersted (1999), s. 18.

29. Om opphavet, se den klassiske fremstillingen til J.G. Starke, «Monism and dualism in the theory of international law», British Yearbook of International Law, 1936, s. 66-81. Den kanskje mest sentrale tyske fremstilling er H. Triepel, Völkerrecht und Landesrecht, Leipzig 1899. Den tyske posisjonen bygger på Hegels dogme om statsviljen, som innebærer at folkeretten har et kontraktsrettslig grunnlag - og bygger på pacta sunt servanda. EU-retten er et eksempel på et system som hviler på en annen filosofisk tilnærming, jf. f.eks. opinion 1/91 EØS, premiss 21: «...the EEC Treaty [...] constitutes the constitutional charter of a Community based on the rule of law». Plikten til å etablere og underkaste seg en konstitusjon bygger på Kantiansk tankegods. Forskjellene mellom en avtalebasert og en konstitusjonell tilnærming er mange. For eksempel vil ikke den siste tilnærmingen tillate at traktatbrudd fra en part kan møtes med sanksjoner fra de øvrige - fordi den, billedlig talt, ser på dette som et lovbrudd, ikke et kontraktsbrudd.

30. Nærmere beskrevet for eksempel i St.meld. nr. 89 (1951) s. 35.

31. Se om dette Utenriksdepartementets rettsavdeling, Dok. nr. 3 (1961-62) s. 20; Hiorthøy (1952), s. 19.

32. Nikolaus Gjelsvik, Lørebok i folkerett, Oslo 1915, s. 123. 
Forarbeidene til grunnloven $₫ 115$ distanserte seg fra den gamle tilnærmingen, og fremholdt blant annet at et absolutt dogme om statens suverenitet er uforenlig med eksistensen av folkerett. ${ }^{33}$ Man kan nok også hevde at den eldre doktrinen tilpasset seg praktiske problemer ved å omgå dem, for eksempel gjennom postulatet om at folkerettslige forpliktelser i det hele tatt ikke utfordrer statens suverenitet. Da kan man risikere å havne i den motsatte grøften: Som illustrert av Gjelsviks posisjon er den gamle doktrinens paradoks at den setter suvereniteten så høyt at vernet av den opphører. Etterkrigstidens store oppfinnelse var en tredje vei: kollektivisering av suverenitet. Mer om det senere.

\subsection{2 "Selvstendighet" versus "uavhengighet"}

Den som mest elegant har forsøkt å oppstille et forsvar for de eldre dogmene, også i en moderne norsk kontekst, er nok tidligere ekspedisjonssjef i Lovavdelingen, Inge Lorange Backer. Backer tok utgangspunkt i ordlyden i grunnloven $₫ 1$, som statuerer at Norge er et fritt, selvstendig, udelelig og uavhendelig rike. Begrepet «selvstændigt» kom inn til erstatning for 17-mai-grunnlovens term "uafhængigt» da Norge gikk inn i Unionen med Sverige i november 1814. Med utgangspunkt i distinksjonen selvstendig/uavhengig kan man ifølge Backer. ${ }^{34}$

språklig oppfatte forholdet mellom uavhengighet og selvstendighet slik: Uavhengigheten sikter til statens evne til å treffe vedtak upåvirket av utenforstatlige organer andre stater eller internasjonale organisasjoner. Selvstendigheten angir evnen til selv å treffe vedtak som regulerer rettsstillingen på norsk territorium. En stat kan med en slik språkbruk ha selvstendigheten i behold selv om uavhengigheten er begrenset. Men selvstendigheten vil være begrenset hvis utenforstatlige organer bindende kan regulere rettsstillingen på norsk territorium, eller hvis de kan avskjære norske statsorganer fra å gjøre dette.

Vi ser at distinksjonen i gjeldende norsk konstitusjonell praksis mellom folkerettslig virkning og direkte (internrettslig) virkning føres i ubrutt linje tilbake til ordlyden i grunnloven $\$ 1$ og dens term «selvstendig». Backers resonnement er kan-

33. Slik St.meld. nr. 89 (1951), s. 3, i samme retning Utenriksdepartementets rettsavdeling, Dok. nr. 3 (1961-62) s. 20, se også Alf Ross, Lerebog i Folkeret, 6 udg., København 1984, s. 51. Dette rammer også viljesteorien som sådan, for det finnes ingen rett om man bare er bundet når man selv vil. Som påpekt av Starke (1936), s. 68-69, hviler Hegels dogme om statsviljen på en realpolitisk overbevisning, som fra et filosofisk perspektiv kan fremstå som «unproved and irrational» og som «always appeared to lack a judicial foundation».

34. Inge Lorange Backer, «Er Norge fortsatt en selvstendig stat?» i Rettsteori og rettsliv: Festskrift til Carsten Smith, Oslo 2002 s. 43-58 (s. 44). 
skje det eneste mulige forsvar for gjeldende rett, samtidig som dets transparens åpner for kritikk, og for å vise hvorfor premisset som gjeldende rett hviler på, vanskelig kan stå seg.

Om vi foreløpig holder oss til Backers egen argumentasjonslinje, så er et første problem at en språklig distinksjon mellom begrepene «selvstendig» og «uavhengig» vel så gjerne kan fremstå som etterkantrealisering av et skille som allerede eksisterer, eller som man av pragmatiske årsaker ønsker å rettferdiggjøre. Og om det skulle være intellektuelt mulig å dele dette språklige hårstrået i to, så kan ikke en formell ordlydstolking legitimere den kløften mellom realiteter og formaliteter som vi gjenfinner i gjeldende rett. ${ }^{35} \AA$ legitimere en slik sondring krever substansielle argumenter. Backer trekker frem praksis. Han viser til at historien gir et ytterligere bidrag til å forstå $\$ 1$ i samsvar med hans utlegning. Grunnlovens krav om norsk selvstendighet sto uendret under hele unionen med Sverige - og man gikk ikke tilbake til formuleringen «uafhængigt» ved unionens opphør i 1905. I Gjelsviks bilde slår Backer fast: «Av dette er det nærliggende å slutte at slike innskrenkninger som unionen førte med seg, var forenlige med selvstendighetskravet i $\$ 1 .{ }^{36}$

Til den rettskildemessige vekten av «praksis» er det først å si at maktpolitiske, symbolske og pragmatiske overveielser vel trumfet de juridiske. Eller som Hiorthøy mer lakonisk konstaterer, «det er i det hele tatt noe problematisk å tale om en konstitusjonell praksis i utenrikske saker når det gjelder et land som ikke har sitt eget utenriksstyre». ${ }^{37}$ Verdien av Backers eksempel ligger vel heller $\mathrm{i}$ at det belyser hvilken kamel man må være villig til å svelge om man skal akseptere den tilnærmingen til grunnloven som gjeldende praksis hviler på: Hvis det å overføre folkerettslig kompetanse faller utenfor suverenitetsbegrepet, kan Stortinget, uhindret av grunnloven, gjenopprette unionen med Sverige. Alt som kreves er en flertallsbeslutning, jf. grunnloven $₫ 26$ andre ledd.

\subsubsection{Kritikk}

Backers rettslige oppfatning har, vil jeg tro, øvet avgjørende påvirkning over Lovavdelingens praksis og gjeldende rett. Men tilnærmingen er for dogmatisk. Den mister av syne det internasjonale aspektet, og tillegger grunnloven $₫ 1$ et innhold som er i konflikt med bestemmelsens egen intensjon og med kildematerialet som lå til grunn for vedtakelsen av grunnloven $\$ 115$.

35. Som påpekt av Utenriksdepartementets rettsavdeling, Dok. nr. 3 (1961-62) s. 25: «...ved fortolkningen vil ikke en strengt juridisk analyse av ordene være tilstrekkelig». Også Backer (2002) erkjenner det, s. 43.

36. Backer (2002), s. 45.

37. Hiorthøy (1952), s. 17. 
Jeg starter med grunnloven $₫ 1$. Finn Hiorthøy hevdet i sin tid at bestemmelsen er et symbol, nærmest helt uten betydning for tolkingen av gjeldende rett. ${ }^{38}$ Erklæringen om selvstendighet/uavhengighet kom til fordi Norge var et lite land, under vanskelige kår, som aspirerte mot noe vi kanskje ikke var, eller fordi vi var redd for å miste noe vi bare så vidt hadde. Det har vist seg at det nettopp er små land, i en liknende situasjon, som har tilsvarende bestemmelser i sine grunnlover. Store land, med en lang historie, har det ikke - for suverenitetsprinsippet er uansett opplagt og følger implisitt av grunnlovens rene eksistens. ${ }^{39}$

Hiorthøys oppfatning om at grunnloven $₫ 1$ er helt uten rettslig betydning, har aldri helt vunnet innpass i juridisk teori. Hans standpunkt er interessant, men i noen henseender diskutabelt. Det vi i det minste kan si, er at i lys av bestemmelsens høye aspirasjoner er det ikke treffende å anvende grunnloven $₫ 1$ som argument for å innrømme Norge en mer beskjeden suverenitet enn det som utgjør kjernen $i$ et allment anerkjent suverenitetsbegrep, jf. f.eks. Fleischers definisjon som referert foran i avsnitt 6.1. Det må gjelde også om vi, som Backer, kun resignerer i rent folkerettslige anliggender. Ja, faktisk er det særlig i denne relasjon Hiorthøys kraftsalve er blitt møtt med reservasjoner. Mens Justisdepartementet - før Backers tid - langt på vei kunne følge Hiorthøys resonnement når det gjaldt internrettslige anliggender, pekte det på at $« \$ 1$ som rettslig påbud har sin vesentligste betydning ved at den setter en grense for statsmaktenes adgang til å slutte folkerettslige avtaler». ${ }^{40}$

Et hovedpoeng med $₫ 1$ er å forhindre union med andre land - statsforbund. Etableringen av unionen med Sverige markerer bestemmelsens tilkortkommenhet, heller enn å utgjøre relevant praksis. Historien om unionen blir mer konstruktiv om vi konsentrerer oss om dens oppløsning. ${ }^{41}$ Helt kort kan det lyde slik: Tidligere var den personlige kongemakten som fulgte av grunnloven, reell, blant annet i utenriksspørsmål. Dette var unionens grunnlag. ${ }^{42}$ Parlamentarismens gjennombrudd bygget på, og markerte, et annet syn på forholdet mellom kongemakt og folkesuverenitet enn tidligere. Dette presset frem unionsoppløsningen i 1905. Det reduserte kongens makt. En av konsekvensene var justeringen av grunnloven $\$ 26$ andre ledd i 1931, som fra da av har henvist til prinsippet om folkesuverenitet, og satt dette høyest også i utenrikspolitiske anliggender. Fra da av,

38. Hiorthøy (1952), særlig s. 14-15 og 22.

39. Hiorthøy (1952), s. $12-13$, se tilsvarende Opsahl (1969), s. 496.

40. Justisdepartmentet, Dok. nr. 3 (1961-62) s. 42, utheving i original.

41. Se også Hiorthøy (1952), s. 17, som peker på at den røde tråd under hele unionstiden var Norges kamp mot underordning og for full likestilling.

42. Da termen «uafhængigt» ble erstattet med «selvstændigt» i november 1814, fikk § 1 også tillegget «forenet med Sverige under een Konge», en passus som sto til unionsoppløsningen i 1905. 
om ikke før, har Backers standpunkt vært utdatert. Det innså da også norske myndigheter i årene etter andre verdenskrig. Som vi skal se, hvilte prosessen frem mot vedtakelsen av grunnloven $\$ 115$ på en erkjennelse av at eldre tiders suverenitetsdogme var foreldet, eller "primitivt», for å låne kildenes ord. ${ }^{43}$ De relevante kildene er et direkte oppgjør med Backers tilnærming - 40 år før han formulerte den.

6.4 Utviklingstendensen etter andre verdenskrig - kollektivisering av suverenitet Idéhistorisk er det ikke uvanlig å anvende forholdet mellom det frie individet og staten som metafor for å beskrive forholdet mellom den «suverene» staten og verdenssamfunnet. Frie individer har en plikt til å tre ut av naturtilstanden (krigstilstanden) og til å konstituere en sivilisert stat. På samme vis har selvstendige stater plikt til å konstituere og underkaste seg et fellesskap av stater. ${ }^{44}$ Selv om pliktens filosofiske begrunnelse er nokså identisk i begge tilfeller, kan vi konstatere at dens politiske gjennomslagskraft har vært meget ulik. Individets plikt til å innordne seg staten er så opplagt at en person i det hele tatt ikke vil bli tatt på alvor om han prøver å «melde seg ut». Forsøker man intenst nok på dette, vil man nok i stedet risikere at staten "griper inn». Statene imellom har suverenitetsdogmet vist seg langt mer robust. Etter første verdenskrig var etableringen av Folkeforbundet et forsøk på å legge til rette for mellomfolkelig samarbeid, men fortsatt slik at suverenitetsdogmet oppebar et krav om enstemmighet for å kunne fatte gyldige vedtak. ${ }^{45}$

Det skulle en ny verdenskrig til for å tvinge igjennom erkjennelsen av at mellomfolkelige organisasjoner, med kompetanse til å binde medlemsstatene også i fravær av deres individuelle samtykke, er nødvendig. Dogmet om statenes absolutte suverenitet ble forlatt. ${ }^{46}$ Internasjonalt rettet man i stedet oppmerksomheten mot betingelsene for å redusere eller avstå suverenitet. FNs Charter (1945) slår fast at organisasjonen er basert på prinsippet om «the sovereign equality of all its Members» (art. 2.1). På nasjonalt hold vant en ny idé frem - at man under vilkår av gjensidighet var villig til å akseptere suverenitetsbegrensninger. Uttrykk for tanken om «kollektivisering av suverenitet» finner vi for eksempel i den franske grunnlov av 1946, den italienske av 1947 og den tyske av 1949. ${ }^{47}$ Det kanskje mest berømte symbolet for denne nye tankes endelige gjennombrudd er EU-domstolens avgjørelse i van Gend \& Loos, som slår fast at

43. Utenriksdepartementets rettsavdeling, Dok. nr. 3 (1961-62) s. 20. Slik også St.meld. nr. 89 (1951) s. 4 og Hiorthøy (1952), s. 19.

44. Se nærmere i Tarjei Bekkedal, Frihet, likhet og fellesskap, Bergen 2008, s. 38-41.

45. Se nærmere St.meld. nr. 89 (1951) s. 7-8.

46. Se om dette Utenriksdepartementets rettsavdeling, Dok. nr. 3 (1961-62), s. 20-21.

47. Se om dette Hiorthøy (1952), s. 21, og St.meld. nr. 89 (1951) s. 72. 
the Community constitutes a new legal order of international law for the benefit of which the states have limited their sovereign rights, albeit within limited fields, and the subjects of which comprise not only Member States but also their nationals. ${ }^{48}$

Avgjørelsen har blitt karakterisert som aktivistisk. Den er i hvert fall helt klart politisk, og ligger i grenselandet mellom å finne og å skape rett. Men det viktigste er at tiden var moden. Domstolen så hvilke spørsmål samtiden reiste - og gav det svaret samtiden krevde. ${ }^{49}$ Dette har blitt akseptert av ettertiden, og av alle de nye medlemslandene som senere har kommet til.

\subsection{Om grunnloven $\S 26$ som uttrykk for et ikke-delegasjonsprinsipp}

I Norge fulgte man naturligvis nøye med på den internasjonale utviklingen. Basisdokumentet for det senere arbeid med revisjon og internasjonalisering av grunnloven var Justis- og politidepartementets 84 sider lange utredning «Grunnloven og Norges deltakelse i internasjonale organisasjoner» fra $1951 .{ }^{50}$ Utredningen tok et oppgjør med den gamle formaljuridiske tenkemåten, hvis innhold ble beskrevet slik: ${ }^{51}$

I følge tradisjonell folkerett er det avgjørende kriterium for hvorvidt en stat er selvstendig (suveren), om dens handlefrihet er begrenset ved statsrettslige eller folkerettslige bånd. Selv om de innskrenkninger en stat er undergitt er aldri så dyptgående, f.eks. slik at den i virkeligheten må anses for et protektorat eller en vasallstat, har den etter denne oppfatning sin selvstendighet i behold, forutsatt at den utelukkende er bundet i henhold til traktat. På den annen side skal en stat som i sin forfatningslovgivning har pålagt seg, om enn nokså beskjedne innskrenkninger, ved dette ha forskjertset sin selvstendighet.

Vi kjenner igjen Backers resonnement, og det foran siterte kunne langt på vei vært en oppsummering av gjeldende praksis i 2015. Utredningen fra 1951 forkaster sondringen mellom folkerettslig virkning og internrettslig virkning med følgende begrunnelse: ${ }^{52}$

For så vidt synes det innlysende at en ikke kan søke tilknytning til den ovenfor gjengitte doktrine om at en stats suverenitet er intakt så lenge dens frie selvbestemmelses-

48. Sak 26/62 van Gend en Loos [1963] ECR 1.

49. Se særlig P. Pescatore, «The doctrine of direct effect: an infant disease of Community Law», European Law Review 1983, s.155-177.

50. St.meld. nr. 89 (1951).

51. St.meld. nr. 89 (1951) s. 35, utheving i original.

52. St.meld. nr. 89 (1951) s. 35, utheving i original. 
rett utelukkende er traktatmessig begrenset. Denne lære, som er utviklet under innflytelse av eldre tysk begrepsjurisprudens, er i de senere år bl.a. anfektet av den danske folkerettslærde A. Ross. Den fortjener neppe tilslutning rent alminnelig sett, og må under enhver omstendighet anses uten interesse for behandlingen av spørsmålet om hvilke forpliktelser den norske stat kan påta seg uten å komme i konflikt med den positive forskrift i grunnlovens $\$ 1$. [...] Grunnloven må antas å bygge på et reelt selvstendighetsbegrep, ikke på et formaljuridisk.

Når man stiller spørsmålet presist - kan Kongens utenrikskompetanse, jf. grunnloven $\$ 26$, delegeres? - er det ganske klart at en formaljuridisk tilnærming er uten verdi, med mindre man ønsker å slå seg til ro med det eneste svaret en slik omgåelse vil kunne gi, nemlig at alt er greit - det finnes ingen skranker. Et slikt standpunkt er imidlertid vanskelig å forsvare når man sammenlikner med andre former for myndighet. Med henvisning til denne parallellen la utredningen det motsatte utgangspunktet til grunn: Utenrikskompetansen kan ikke overføres eller delegeres: ${ }^{53}$

Her som i andre forbindelser der det er snakk om delegasjon av statsmyndighet må utgangspunktet være at delegasjon som alminnelig regel ikke kan skje. Når Grunnloven har lagt en spesiell myndighet til et bestemt statsorgan, må den oppfattes derhen at det normalt er dette organ og ingen annen som har rett og plikt til å utøve de beføyelser det er tale om. Dette gjelder også traktatmyndigheten som grunnloven har tillagt Kongen ved bestemmelsen i $\$ 26$ første ledd om at det er ham som har rett til å 'indgaa og ophave Forbund'. For så vidt det må anses for å gå inn under denne bestemmelse når en internasjonal organisasjon med hjemmel i sine vedtekter treffer bestemmelser som er folkerettslig forpliktende for Norge, vil den myndighetsoverføring som danner grunnlaget for vedtaket $\mathrm{i}$ beste fall trenge særskilt begrunnelse.

Det er viktig å understreke at utredningen på dette punkt ikke var et bakstreversk forsøk på å holde fast ved en forståelse av grunnloven $₫ 1$ som tiden hadde løpt fra. Tvert imot anla utredningen en svært åpen holdning til internasjonalt samarbeid, slik dette senere ble stadfestet gjennom vedtakelsen av grunnloven $\$ 115 \mathrm{i}$ 1962. Utredningens oppmerksomhet om det rettslige utgangspunktet skyldes at den formulerte sitt spørsmål mye klarere enn det både fortiden og ettertiden har gjort: ${ }^{54}$ 
Spørsmålet om den grunnlovsmessige tilstedelighet av en slik myndighetsdelegasjon som tilslutning til etterkrigstidens internasjonale organisasjoner innebærer har hittil vært lite påaktet, åpenbart fordi forholdet har hatt mindre praktisk betydning.

Først når man erkjenner utgangspunktet, at myndigheten til å binde Norge folkerettslig ikke helt uten videre kan oppgis til fordel for utenlandske organisasjoner, kan man drøfte det vesentlige: Under hvilke forutsetninger er det likevel tillatelig? Som vi skal se i avsnitt 7 nedenfor, var svaret: Når det skjer mot en andel i den større myndighetens utøvelse - med andre ord: når Norge er medlem. Denne oppfatningen ble formalisert gjennom vedtakelsen av grunnloven $₫ 115$.

\section{Om kollektivisering av suverenitet, medlemskapsprinsippet og grunnloven \$ 115}

\subsection{Innledning}

Til rettsoppfatningen som er beskrevet foran, vil nok mange anerkjenne at den isolert sett kunne vært fornuftig, de lege ferenda. Innvendingen vil være at grunnloven $\$ 115$ bygger på og bekrefter en annen oppfatning, som den rådende grunnlovspraksis legger til grunn, nemlig at det går et grunnleggende skille mellom disposisjoner som bare etablerer folkerettslige forpliktelser, og overføring av intern myndighet. Nedenfor skal jeg vise at en slik oppfatning er for enkel og unyansert, og at grunnloven $₫ 115$ tvert imot tjener til å kodifisere medlemskapsprinsippet.

\subsection{Utgangspunktet}

Justisdepartementets redegjørelse forut for vedtakelsen av grunnloven $₫ 115$ bygger på utredningen «Grunnloven og Norges deltakelse i internasjonale organisasjoner» fra 1951. Av spesiell interesse for vårt vedkommende er departementets analyse av gjeldende rett, under overskriften «Avgjørelser på det folkerettslige plan - utøving av traktatmyndighet». ${ }^{55}$ Essensen i dette avsnittet kan vi utlegge slik: Forut for vedtakelsen av grunnloven $\$ 115$ la Justisdepartementet til grunn at grunnloven $\$ 26$ oppebærer et ikke-delegasjonsprinsipp, og at tilfeller hvor Norge blir folkerettslig forpliktet i internasjonale sammenhenger, kan komme i berøring med dette utgangspunktet. Departementet var likevel av den oppfatning at «en ikke ubetinget [kan] anse Norge forfatningsmessig avskåret fra å gå med på en ordning som gir internasjonale organer myndighet til å gjøre folkerettslig bindende vedtak for landet». Etter departementets oppfatning var det åpning i grunnloven $\$ 26$ for å overlate myndighet til internasjonale organisasjoner som landet

55. Justisdepartementet, Dok. 3 (1961-62) s. 45. 
blir medlem av, for å fremme fred og internasjonalt samarbeid i alle medlemsstaters interesse. Samtidig understreket departementet at det «skal mye til» for å akseptere ordninger som overlater myndighet til et internasjonalt organ der Norge ikke er representert.

Noen av formuleringene kan gi assosiasjoner til en doktrine om «lite inngripende» myndighetsoverføring. En lære om «lite inngripende» myndighetsoverføring markerer at de bakenforliggende bestemmelser som læren tjener til å modifisere, er for ikke-delegasjonsprinsipper å regne. I dag blir læren utelukkende knyttet til overføring av intern kompetanse. Men i tråd med samtidens oppfatning om at utenrikskompetansen i utgangspunktet ikke kan delegeres, er den nok primært utviklet med denne type kompetanse for øye. I juridisk teori var Erik Colban en av de første som drøftet en slik lære, og da med utenrikskompetansen som objekt. $^{56}$

I dag blir læren om «lite inngripende» myndighetsoverføring gjerne tilskrevet Carl August Fleischer, og den blir kun anvendt ved overføring av intern kompetanse. ${ }^{57}$ Fleischer hadde vært involvert i arbeidet med Justisdepartementets og Utenriksdepartementets utredninger forut for vedtakelsen av grunnloven $₫ 115$, som førstesekretær i UD. Fleischers artikkel fremstår på mange punkter som en syntese av de to departementenes utredninger, derav kanskje dens gjennomslagskraft. Også Fleischer var naturligvis opptatt av tidens store og mest aktuelle spørsmål, norsk medlemskap i internasjonale organisasjoner, og artikkelen innleder med å behandle dette. På samme måte som Justisdepartementet brukte Fleischer norsk medlemskap i FN som eksempel. ${ }^{58}$

En kan hevde at læren om «lite inngripende» myndighetsoverføring ble utviklet med overføring av utenrikskompetanse for øye, og at den markerte en oppfatning om at denne myndigheten i utgangspunktet ikke kan delegeres. Senere har det skjedd en glidning, som har kulminert i en fullstendig transformasjon - slik at læren i dag utelukkende blir anvendt i relasjon til intern kompetanse. Om den opprinnelige læren i det hele tatt knyttet an til dette, i tillegg til overføring av utenrikskompetanse, er faktisk ikke helt opplagt. Andenæs tok for eksempel til orde for at adgangen til å overføre intern kompetanse måtte bero på en tolking av grunnlovens respektive kompetansebestemmelser. Han understreket i den forbindelse at dette «spørsmål er et annet enn spørsmålet om hva grunnlovens $₫ 1$ tillater», en

56. Erik Colban, Stortinget og utenrikspolitikken, Oslo 1961. Colban sondret mellom overføring av traktatmyndighet i snever forstand (s. 187) og overføring av myndighet til organisasjoner Norge er medlem av (s. 190).

57. Carl August Fleischer, «Grunnloven § 93», Jussens Venner 1963, s. 73-111.

58. Justisdepartementet, Dok. 3 (1961-62) s. 43, Fleischer (1963), s. 78-79. 
holdning som vel underminerer det som i dagens praksis blir ansett som hjemmelsgrunnlaget for læren om «lite inngripende» myndighetsoverføring. ${ }^{59}$ Det er mulig å lese Fleischer på samme måte, slik at kriteriet «lite inngripende» ikke er ment som en selvstendig lære i relasjon til overføring av intern kompetanse, men kanskje mer som en empirisk observasjon, som var ment å sammenfatte status for eksisterende tolkingspraksis. Leser man Fleischer nøye, ser man at han først understreker at det bare er der grunnlovens respektive kompetansebestemmelser etter sitt eget innhold er til hinder for å overføre myndighet at man må ty til grunnloven $₫ 115$. Og i forlengelsen oppstiller faktisk Fleischer aldri kriteriet «lite inngripende», som er blitt tilregnet ham, og som jo kan lyde som en selvstendig rettslig standard. Fleischer konstaterer bare det mer beskrivende: at man må anvende substitusjonsbestemmelsen i $\$ 115$ når en myndighetsoverføring er «inngripende» - dvs., slik jeg forstår dette, der myndighetsoverføringen ellers vil krenke de av grunnlovens kompetansebestemmelser som blir berørt. ${ }^{60}$

\subsection{Kollektivisering av suverenitet}

Justisdepartementets beskrivelse av gjeldende rett ovenfor viser at oppgivelsen av det gamle suverenitetsdogmet, til fordel for betraktninger om kollektivisering av suverenitet, hadde begynt å øve innflytelse over tolkingen av grunnloven allerede før $\$ 115$ ble vedtatt. Samtidig skapte den nye dynamikken uklarhet. Dermed fikk grunnloven $₫ 115$ et dobbelt formål: dels å presisere rettstilstanden, dels å lette muligheten for internasjonalt samarbeid. ${ }^{61}$

Fra det store tilfanget av forutgående vurderinger kan vi merke oss at Stortingets avsluttende innstilling om $\$ 115$ kun inneholder to sitater - først denne gjengivelsen fra 1951-utredningen, hvor det gamle suverenitetsdogmet ble oppgitt: ${ }^{62}$

Verden er én, og hvis menneskeheten skal ha en fremtid, kan veien bare gå gjennom en radikal utvidelse av det mellomstatlige samvirke på alle områder. Overfor denne erkjennelse som i dag ikke bare hylles av alle ledende statsmenn i den demokratiske verden, men også har forplantet seg til vide kretser av befolkningene, har det tradisjonelle suverenitesdogme ikke kunnet holde stand.

59. Andenæs, Dok. 3 (1961-62) s. 11. Dette henger sammen med at Andenæs, s. 13, som Justisdepartementet i samme dokument, s. 42, i første rekke betraktet grunnloven $\S 1$ som relevant for bedømmelsen av folkerettslige forpliktelser. Se også Hiorthøy (1952), s. 23.

60. Fleischer (1963), s. 89, jf. 93. Se også note 17, hvor Fleischer gir tilslutning til Andenæs' sammenfallende synspunkt.

61. Innst. S. nr. $100(1961-62)$ s. 138.

62. Innst. S. nr. 100 (1961-62) s. 138 med henvisning til St.meld. nr. 89 (1951) s. 43, også sitert av Utenriksdepartementets rettsavdeling, Dok. nr. 3 (1961-62) s. 21 (utheving i original). 
Videre gjengir stortingsinnstillingen uttalelsene fra Utenriksdepartementets rettsavdeling om hva som erstatter det gamle dogmet: ${ }^{63}$

Tendensen i denne organisasjonen av folkerettssamfunnet synes klar. Den absolutte suverenitetstanke har veket plassen for en oppfatning av statsbegrepets muligheter og funksjoner som svarer til de aktuelle internasjonale problemer. Enstemmighetsprinsippet vil i stigende utstrekning måtte vike plassen for flertallsvedtak. Mulighetene for å melde seg ut av en organisasjon fordi vedkommende stat er uenig i dens politikk, vil måtte begrenses. Vedtak av internasjonale organisasjoner må i et hvert fall på mer begrensede områder være bindende direkte for de enkelte medlemsstater og likeledes $\mathrm{i}$ en viss utstrekning kunne håndheves direkte på statsterritoriet på linje med statsorganenes egen lovgivning og administrative avgjørelser.

Hvorfor slike lange sitater? - jo, for å kunne stille disse retoriske spørsmål før vi nedenfor skal tolke grunnloven $\$ 115$, slik den ble formet: Er det grunn til å nærme seg bestemmelsens vedtakelse som den endelige kodifiseringen av den gamle tyske doktrinen om et skille mellom folkerettslig og statsrettslig («direkte») virkning - omtrent slik Backer utlegger sondringen? Var bestemmelsen ment å grunnlovsfeste et suverenitetsdogme som forarbeidene og samtiden ikke bare beskrev som "primitivt», men som Utenriksdepartementets rettsavdeling tilla ansvaret for utbruddet av andre verdenskrig, ${ }^{64}$ og som stortingsinnstillingen betrakter som foreldet?

I norsk juridisk litteratur har svaret tilsynelatende vært ja. Backer er nevnt. Fredrik Sejersted skriver seg inn i samme tradisjon. ${ }^{65}$ Det gjør også Fredrik Lilleby. ${ }^{66}$ Eirik Holmøyvik slutter seg til. ${ }^{67}$ Et unntak er professor Erik Boes klare tale: «Det er for kategorisk, ja, det er historieløst og i virkeligheten lite dekkende for statsrettstradisjonen ene og alene å bygge grensedragningen for $\$ 26$ på skillet mellom direkte virkning og folkerettsvirkning.. ${ }^{68}$

For egen del forstår jeg grunnloven $₫ 115$ slik: Vedtakelsen av bestemmelsen markerer, også for norsk retts vedkommende, at det tradisjonelle dogmet om statenes absolutte og uinnskrenkede handlefrihet er forkastet, og det med en tydelighet og i et ordelag som man ikke ofte finner i offentlige dokumenter. Med dette

63. Innst. S. nr. 100 (1961-62) s. 138 med henvisning til Utenriksdepartementets rettsavdeling, Dok. 3 (1961-62) s. 21.

64. Utenriksdepartementets rettsavdeling, Dok. nr. 3 (1961-62) s. 20.

65. Sejersted (1999), s. 17.

66. Lilleby (2010), s. 17.

67. Holmøyvik (2011), s. 449.

68. Erik Boe i Sejersted \& Boe (1999), s. 83. 
forsvinner også den gammeldagse og primitive sondringen mellom folkerettslig og internrettslig virkning. Bestemmelsens formål er å klargjøre at innskrenkninger av norsk handlefrihet er greit så lenge det skjer som ledd i gjensidig kollektivisering av suverenitet. For prinsipielt og praktisk å sikre Norge andel i den kollektive myndighetens utøvelse stadfester grunnloven $\$ 115$ medlemskapsprinsippet.

\subsection{Grunnloven § 115 som uttrykk for medlemskapsprinsippet}

\subsubsection{Forarbeidene}

Dagens rådende rettsoppfatning anerkjenner at grunnloven $₫ 115$ stadfester medlemskapsprinsippet, så langt det gjelder overføring av intern myndighet. Skal man overføre lovgivende, administrativ eller dømmende myndighet i medhold av grunnloven $\$ 115$ første ledd, er forutsetningen at det skjer til fordel for en organisasjon som Norge er medlem av. ${ }^{69}$ Til sammenlikning har medlemskapsprinsippet og dets betydning ikke vært fremme ved spørsmål om grunnlovsmessigheten av traktater som kun skaper folkerettslige virkninger.

I pakt med at forarbeidene toner ned sondringen mellom folkerettslig og internrettslig virkning, anlegger de en helhetlig tilnærming til medlemskapsprinsippet. Betraktninger om kollektivisering av suverenitet, og om medlemskapsprinsippets rolle, finner vi særlig i Justisdepartementets redegjørelse for grunnloven $\$ 1$. Når det gjelder dagens lære, har vi sett at denne bestemmelsen enten er en uttalt referanse, ${ }^{70}$ eller en innforstått forutsetning, ${ }^{71}$ som bærer utgangspunktet om at «staten er herre i eget hus» - internrettslig. Til forskjell fra dette var departementets fremstilling generell, dog slik at departementet la hovedvekten på overføring av folkerettslig myndighet (departementets uthevinger): ${ }^{72}$

$\ldots \S 1$ som rettslig påbud har sin vesentligste betydning ved at den setter en grense for statsmaktenes adgang til å slutte folkerettslige avtaler. [...] Det har ikke vært funnet grunnlovsstridig at Norge er med i FN, enda landet da uten vetorett plikter å sette i verk sanksjoner som Sikkerhetsrådet bestemmer [...]. Ellers har imidlertid den alminneligste internasjonale samarbeidsform vært at vedtak krever tilslutning fra alle saken angår, slik at Norge ikke kan forpliktes mot sin vilje. Dette er f.eks. tilfelle med EFTA.

Det synes rimelig å ta som utgangspunkt at Grunnlovens bestemmelser om rikets frihet og selvstendighet ikke er gått for nær så lenge Norge ikke kommer i et ensidig

69. Fredrik Sejersted, «Læren om «lite inngripende» myndighetsoverføring - statsrettslig selvbedrag eller fornuftig grunnlovstolking?» Nytt Norsk Tidsskrift 2013, s. 416-422 (s. 420).

70. JDLOV-1997-5405 Voldgiftsklausuler i bilaterale investeringsbeskyttelsesavtaler.

71. Tverberg (2014).

72. Justisdepartementet, Dok. 3 (1961-62) s. 43 (utheving i original). 
avhengighets- eller underordningsforhold til noen bestemt fremmed stat eller gruppe av stater, men deltar som likeverdig medlem i mellomfolkelige organisasjoner opprettet for å løse medlemmenes felles oppgaver. Avgjørende må være at Norge er berettiget i samme eller tilsvarende forhold som de andre medlemmer når det gjelder mulighetene for å øve innflytelse ved å delta i forberedelser, forhandlinger og avstemning.

Det synes etter dette å være på det rene at man ved vedtakelsen av grunnloven $\$ 115$ også hadde overføring av utenrikskompetanse for øye, og ville stadfeste at medlemskapsprinsippet gjelder også i dette henseende.

\subsubsection{Grunnloven § 115 - ordlyd og systematikk}

Som understreket da artikkelens tese ble presentert foran: Verken bestemmelsens ordlyd eller systematikk gir grunnlag for å hevde at grunnloven $₫ 115$ oppstiller en skarp sondring mellom internrettslig og folkerettslig kompetanse. Utenrikskompetansen er en av de «beføyelser» grunnloven konstituerer, jf. $\$ 115$ første ledd. Medlemskapsprinsippet kommer til uttrykk i begge ledd.

Én mulig ordlydsforståelse er at grunnloven $₫ 115$ første ledd omfatter enhver overføring av myndighet. Med en slik forståelse vil bestemmelsens andre ledd kun tjene til å presisere at mer tradisjonelle former for samarbeid ikke er berørt: Norsk innmelding i organisasjoner som ikke får overført beslutningsmyndighet, men hvis vedtak i stedet forutsetter enstemmighet, vil ikke kreve beslutning med kvalifisert flertall. ${ }^{73}$

En annen mulig tolkning er å anse grunnloven $\$ 115$ som en presisering av hvordan ikke-delegasjonsprinsippet i grunnloven $\$ 26$ er å forstå, hvor langt det rekker. Man kan hevde at grunnloven $\$ 115$ andre ledd presiserer det som et stykke på vei var antatt å gjelde allerede før vedtakelsen: Selv om grunnloven $\$ 26$ legger utenrikskompetansen til Kongen, er ikke det til hinder for at Norge overfører kompetanse til å binde Norge folkerettslig til en organisasjon Norge er tilsluttet som likeverdig medlem. En slik tolking av $\$ 115$ åpner for at Stortinget kan beslutte innmelding i denne type organisasjoner med alminnelig flertall.

Begge tolkningene foran respekterer medlemskapsprinsippet, og jeg skal ikke her drøfte nærmere hvilken forståelse som er den korrekte. Det viktige i denne omgang er at alternativene distanserer seg fra en tredje forståelse. Sejersted er representant for en ikke uvanlig, men svært selektiv tilnærming til ordlyden når han kun siterer ordene «rent Folkeretslig Virkning» i grunnloven $\$ 115$ andre ledd. ${ }^{74}$ Utvelgelsen innebærer at Sejersted ser helt bort fra det språklige uttrykket

73. Fleischer (1963), s. 85, kan forstås slik, men andre uttalelser går i motsatt retning, for eksempel på s. 87.

74. Sejersted (1999), s. 17. 
for medlemskapsprinsippet, som kan hevdes å være det mest vesentlige. I forlengelsen understreker og viderefører Sejersted sondringen mellom folkerettslig og internrettslig virkning, som vi har sett at forarbeidene tok et oppgjør med. Med henvisning til Andenæs hevder Sejersted at det å oppstille en slik sondring også hadde støtte i debatten fra før 1962, men at uttalelsene fra den gang ikke var like absolutte som ordlyden i grunnloven $\$ 115$ til slutt ble. ${ }^{75}$

Analysen foran viser at grunnloven $₫ 115$ langt fra er absolutt om man tar alle ordene den inneholder, i betraktning, tvert imot. Når det gjelder Andenæs' tilnærming, trakk han veksler på den gamle sondringen mellom folkerettslig og internrettslig virkning (s. 13), men først etter å ha understreket forutsetningen (s. 11): at det var snakk om «et samarbeid mellom likestilte stater i felles interesse». ${ }^{76}$ I store trekk synes det som om oppfatningene til Andenæs var på linje med den generelle holdningen i det akademiske miljøet, nemlig at det er en viss forskjell mellom folkerettslig virkning og direkte virkning, men at denne ikke bør overdrives. ${ }^{77}$

\subsubsection{Etterfølgende forståelse}

De for ettertiden viktigste forståelsene av medlemskapsprinsippet i grunnloven $\$ 115$ kommer til uttrykk i betenkninger fra Castberg, Andenæs og Opsahl i Dokument nr. 10 (1966-67). Dette dokumentets betydning skyldes for det første at man her ikke bare drøfter muligheten for medlemskap i Fellesskapet, men også assosiering, altså deltakelse uten medlemskap. For det andre har standpunktene i Dokument nr. 10 (1966-67) blitt ansett som autoritative av ettertiden, og er alltid blitt vist til i senere offentlige dokumenter, ${ }^{78}$ dog kanskje uten at man har hatt den fulle forståelse av standpunktenes premisser og prinsipielle implikasjoner.

I forkant av at betenkningene ble innhentet, hadde spørsmålet om norsk assosiering blitt drøftet av det såkalte Markedsutvalget. Utvalget antok at en assosieringsavtale aldri ville kunne innebære en større overføring av myndighet til Fellesskapet enn fullt medlemskap. Fra det mer til det mindre mente derfor Markedsutvalget at om grunnloven først gav hjemmel for å melde Norge inn i Fellesskapet, måtte grunnloven også kunne hjemle assosiasjon. I sin respons til dette påpekte Andenæs at Markedsutvalgets standpunkt syntes å overse selve forutsetningen i

75. Sejersted (1999), s. 17, med henvisning til Andenæs, Dok. nr. 3 (1961-62) s. 13.

76. Andenæs, Dok. nr. 3 (1961-62) s. 11 og 13; sml. Andenæs, Dok. nr. 10 (1966-67) s. 13 og henvisningen til dette og ytterligere materiale fra Andenæs i St.prp. nr. 50 (1998-99) Schengen, s. 34.

77. F.eks. Hiorthøy (1962), s. 27, sitert i Justisdepartementet Dok. Nr. 3 (1961-62) s. 43, som også viser til Castbergs kritikk av sondringen mellom folkerettslig og internrettslig virkning, se Frede Castberg, Forhandlinger på det tyvende nordiske juristmote, Oslo 1956, s. 78.

78. Se f.eks. St.prp. nr. 100 (1991-92) EØS, s. 344-345; St.prp. nr. 42 (1996-97) s. 17; Innst. S. nr. 229 (1996-97) s. 8; St.prp. nr. 50 (1998-99) Schengen, s. 32. 
$\$ 115$, at «Norge blir medlem i sammenslutningen og deltar i dens organer på linje med de øvrige medlemmer». ${ }^{79}$ Utover å løfte frem problemet nøyde Andenæs seg med å vise til at Opsahl ville utrede spørsmålet nærmere.

I sin utredning understreket Opsahl at det «utvilsomt er et selvstendig vilkår» i $\$ 115$ at Norge er med i den sammenslutningen som skal utøve myndighet. Det gjelder selv om fordelene ved en assosieringsavtale gir fordeler som oppveier pliktene som følger med på kjøpet. Denne motviljen mot pragmatisme begrunnet Opsahl prinsipielt, med henvisning til at grunnloven $₫ 115$ hviler på idéen om kollektivisering av suverenitet: «[M]yndighetsoverføring, slik jeg forstår $\$ 115$, [kan] bare skje mot andel i myndighetens utøvelse.» ${ }^{80}$

Så kan man si: vel og bra, men dette er både kjent og anerkjent i gjeldende praksis, for så vidt gjelder overføring av intern kompetanse. En avgrensning mot overføring av utenrikskompetanse fremstår imidlertid som umulig å begrunne prinsipielt, om man først aksepterer at betraktningen om kollektivisering av suverenitet er resonnementets - og medlemskapsprinsippets - grunnlag. Helt i samsvar med den, etter min oppfatning, klare ordlyden i grunnloven $\$ 115$ var da også Opsahls betraktning generell: ${ }^{81}$

Dette kan neppe komme an på hvorvidt plikten til å følge EEC’s vedtak [...] skulle ha direkte virkning som norsk rett, eller om den ble formet som en folkerettslig plikt som deretter formelt måtte transformeres til norsk rett. Selv om $₫ 115$, annet ledd, gjør unntak for organisasjoner hvis vedtak bare har folkerettslig virkning for Norge, gjelder det også her organisasjoner Norge deltar i. Det fremgår av teksten. En slik folkerettslig plikt overfor en organisasjon Norge ikke er med i, ville være noe nytt. Den kunne etter min mening heller ikke stiftes ved vanlig traktat etter grl. $\$ 26$, med mindre plikten var av uvesentlig betydning. Ellers ville den også lett stride mot prinsippet i grl. $\$ 1$.

Det er altså ikke noe oppsiktsvekkende eller revolusjonært syn på ordlyden i grunnloven $\$ 115$, eller medlemskapsprinsippets rekkevidde, som jeg har tatt til orde for foran. Det oppsiktsvekkende er egentlig hvordan de eldre betraktningene er sett bort fra, og hvordan dagens praksis har konservert en sondring mellom internrettslig og folkerettslig virkning som forarbeidene til grunnloven $₫ 115$ tok et oppgjør med.

79. Andenæs, Dok. nr. 10 (1966-67) s. 13.

80. Opsahl, Dok. nr. 10 (1966-67) s. 29.

81. Opsahl, Dok. nr. 10 (1966-67) s. 29. 


\section{Om gjennomskjæring}

\subsection{Innledning}

Formelt er Norges avtaler med EU konstruert slik at de i all hovedsak ikke overfører myndighet - verken intern kompetanse, eller myndighet til å binde Norge folkerettslig. Reelt har Norge ikke noe annet valg enn å følge den europeiske rettsutviklingen, så sant samarbeidet skal bestå. Når man vurderer forholdet mellom slike avtaler og grunnloven, er dette blitt betraktet som et spørsmål om når man eventuelt skal skjære gjennom, og legge avgjørende vekt på realitetene.

Gjennomskjæring er en anerkjennelse av formålet og intensjonen til rettsreglene på et område. Derfor vil måten vi forstår grunnloven på, definere gjennomskjæringsregelens funksjon og styrke. Slik dagens konstitusjonelle praksis har utlagt reglene om myndighetsoverføring, vil gjennomskjæring i praksis være nesten utenkelig. Det er to grunner til dette. For det første er det vanskelig å oppstille et objektivt og nogenlunde klart kriterium som angir når man skal gå fra formalitet til realitet. For det andre passer gjennomskjæring best i tilfeller hvor aktørene omgår rettsreglene. I vårt tilfelle lyder gjeldende doktrine «vær formell, se bort fra realitetene», og da skjer det ikke egentlig noen omgåelse om man så gjør. Når man lojalt følger doktrinen, er det vanskelig å skjære gjennom bare fordi resultatet på et eller annet tidspunkt er lite spiselig. Det siste ville langt på vei være det samme som å blåse liv i skranken «ånd og prinsipper», jf. grunnloven $₫ 121$.

Bevissthet om medlemskapsprinsippet vil bidra til større klarhet fordi det blir mye tydeligere hva omgåelsen består i. Dels kan det innebære en annen og lavere terskel for gjennomskjæring.

\subsection{Gjennomskjæringsregel nr. 1 - fra formalitet til realitet}

I Lovavdelingens praksis finner vi ingen konkrete eksempler på at gjennomskjæring har funnet sted. Derimot finner vi flere uttrykk for at gjennomskjæringsregler er antatt å eksistere: Den første regelen angår gjennomskjæring fra formalitet til realitet, og lyder omtrent slik: ${ }^{82}$

Myndigheten til å binde Norge folkerettslig kan normalt overføres på grunnlag av grunnloven $\$ 26$. Det er likevel antatt at det går en grense for hvor omfattende myndighet som kan overføres i medhold av denne bestemmelsen. Ved meget omfattende overføring av myndigheten til å binde Norge folkerettslig kan det være påkrevet å innhente Stortingets samtykke jf. grunnloven $\$ 115$ første ledd.

82. Parafrase over formuleringene i St.prp. nr. 50 (1998-99) Schengen, s. 43 og JDLov 1997-5405 Voldgiftsklausuler i bilaterale investeringsbeskyttelsesavtaler, punkt 7.3.2. 
Tankerekken som ligger bak denne mulige gjennomskjæringsregelen, er at det å overføre myndighet til å binde Norge folkerettslig til slutt vil gi seg utslag i intern norsk rett. Praktisk og materielt er konsekvensene langt på vei de samme som ved overføring av intern myndighet. Det er dette Schengen-proposisjonen har for øye når den fremholder at grunnloven $\$ 115$ første ledd, om overføring av intern myndighet, «kan tenkes å få anvendelse dersom det dreier seg om meget omfattende overføring av kompetanse til å binde Norge folkerettslig». ${ }^{83} \mathrm{I}$ den forbindelse understreker imidlertid proposisjonen at «listen for hvor mye myndighet grunnloven tillater overført i medhold av $\$ 26$ annet ledd, må ligge betydelig høyere når det gjelder overføring av kompetanse til å forplikte Norge folkerettslig...». ${ }^{84}$ Det virker imidlertid ikke særlig logisk at terskelen er «betydelig høyere» fordi det «bare» er snakk om folkerettslig binding - dersom premisset for at man skjærer gjennom er at dette i realiteten får internrettslige konsekvenser.

Hvis vi forutsetter at det virkelig er snakk om overføring av myndigheten til å binde Norge folkerettslig, så viser vel egentlig forsøket på å formulere en gjennomskjæringsregel at man må ha tråkket feil i rettsanvendelsesprosessen frem til dette punkt. Så lenge Norge først er medlem, oppstiller grunnloven $₫ 115$ første ledd ingen substansiell grense for adgangen til å overføre intern myndighet. Da må det samme klart nok gjelde ved overføring av myndighet til å binde Norge folkerettslig til en organisasjon Norge er medlem av. Det følger utvetydig av grunnloven $₫ 115$ andre ledd, jf. grunnloven $₫ 26$. I den grad grunnloven $₫ 1$ isolert sett kunne ledet til en annen konklusjon, må bestemmelsen anses for å ha blitt endret gjennom vedtakelsen av $\$ 115.85$

Hvis Norge på den annen side ikke er medlem, har analysen foran i artikkelen vist at adgangen til å overføre en omfattende kompetanse til å binde Norge folkerettslig uansett ikke er til stede.

Betraktningen Schengen-proposisjonen fremsetter - at det finnes tilfeller hvor overføringen av folkerettslig myndighet er så betydelig at Stortinget også i dette henseende må avgi samtykke på grunnlag av grunnloven $₫ 115$ første ledd, som om det var snakk om overføring av intern myndighet - er vanskelig å innplassere i grunnlovens system. Om Stortinget først skal fatte et $\$ 115$ første ledd-vedtak, er det ubestridt at Norge må være medlem av organisasjonen. Hvis man i forbindelse med Schengen-samarbeidet hadde kommet til at grunnloven $\$ 26$ ikke var tilstrekkelig som hjemmel, er det på det rene at også grunnloven $₫ 115$ første ledd ville vært uanvendelig siden Norge ikke er EU-medlem. Og om det i stedet dreier

83. St.prp. nr. 50 (1998-99) Schengen, s. 43. 84. St.prp. nr. 50 (1998-99) Schengen, s. 44. 85. I samme retning Opsahl (1969), s. 507. 
seg om tilfeller hvor Norge tenker å bli medlem av en folkerettslig organisasjon, virker deklarasjonen i grunnloven $\$ 115$ andre ledd like klar: Overføring av myndighet til å binde Norge folkerettslig kan vedtas med simpelt flertall. Konstruksjonen som Schengen-proposisjonen ser for seg, at inngåelse av en rendyrket folkerettslig avtale skal måtte vedtas av Stortinget med 3/4 flertall, virker altså umulig, om Norge er medlem eller ei.

\subsection{Gjennomskjæringsregel nr. 2 - "fritt og selvstendig rike"}

Formelt kjennetegnes Norges avtaler med EU av at de verken overfører myndighet til å binde Norge folkerettslig eller myndighet til å fatte beslutninger som vil være direkte bindende i intern norsk rett. Med sikte på slike tilfeller har det gjennom praksis blitt utviklet en annen gjennomskjæringsregel, hvor man vurderer om $^{86}$

avtalen samlet sett innebærer myndighetsoverføring i strid med Grunnloven. Vurderingstemaet er her ikke Grunnlovens enkelte kompetansebestemmelser, men Grunnlovens system mer generelt, og $₫ 1$ spesielt.

Stikkordet i denne forbindelse er vel «samlet sett», snarere enn «myndighetsoverføring», i og med at myndighetsoverføring jo ikke finner sted, formelt sett. Poenget er at det skal skje en avsluttende helhetsvurdering hvor også realitetene i noen grad blir tatt i betraktning, og hvor spørsmålet er om Norge «alt i alt» kan sies å miste sin status som fritt og selvstendig rike.

En slik gjennomskjæringsregel kom inn som en del av liturgien fra og med Schengen-proposisjonen, og kan synes å bygge på Erik Boes forutgående utredning. Boe, som fant at Schengen-samarbeidet isolert sett ikke krenket noen av grunnlovens bestemmelser, oppstilte følgende resonnement om at summen av det hele ikke må bli for stor: ${ }^{87}$

Etter å ha vurdert hver dimensjon i forhold til Grunnloven $₫ 1$, i forhold til grunnlovens kompetansesystem og ved å kumulere de to skrankene, må det foretas en samlet vurdering av de enkelte elementene [...] ut fra tankegangen: Renner begeret over, selv om det ikke renner over på hvert punkt.

Som grunnlag for sitt beger-resonnement påberopte Boe seg en statsrettstradisjon formulert av bl.a. Castberg, Andenæs og Opsahl. Jeg har imidlertid ikke funnet

86. St.prp. nr. 50 (1998-99) Schengen, s. 44 (utheving i original). Se i samme retning JDLov 1997-5405

Voldgiftsklausuler i bilaterale investeringsbeskyttelsesavtaler, punkt 7.3.2.

87. Boe (1999), s. 68-69. 
klare eksempler på at disse var tilhengere av «en samlet helhetsvurdering». Tvert imot. Andenæs understreket betydningen av å holde grunnlovens ulike bestemmelser fra hverandre, og Opsahl forutså og tok avstand fra Boes tilnærming 30 år tidligere. $^{88}$

Det virker nærmest utenkelig at den siste gjennomskjæringsregelen kan føre frem. Det skyldes dels at man vanskelig kan forestille seg samarbeid gjennom internasjonale organisasjoner som er i konflikt med slike internasjonale oppfatninger om suverenitet som den norske grunnlovens innhold må fastlegges i lys av. Når det gjelder Norges selvstendighet, som beskyttet av grunnloven $\$ 1$, kan man antakelig se det slik at denne alltid er i behold så lenge det ikke skjer en overføring av myndighet i formell forstand. Selvstendighetsbegrepet er utpreget formelt, og kjennetegnes av at retten til å si nei må være i behold. Er den det, blir henvisningen til realitetene mest en avsporing - for det er ikke her skoen trykker.

\subsection{Det egentlige problemet - omgåelsen av medlemskapsprinsippet}

Beskyttelsen av norsk suverenitet, som følger av at avtalene med EU bare innebærer en reell, ikke en formell overføring av suverenitet, etablerer en garanti for at Norge kan si nei til forpliktelser som ikke er til å leve med. Den som kan si nei til videre samliv, har sin selvstendighet i behold. Norge er fortsatt en suveren stat. Men grunnlovens medlemskapsprinsipp handler om noe helt annet - nemlig samlivet. Medlemskapsprinsippet skal sikre gjensidighet, påvirkning og demokratisk deltakelse ved utformingen av de forpliktelsene man velger å leve med, de forpliktelsene man ikke sier nei til.

Om vi aksepterer at grunnloven bygger på en tanke om kollektivisering av suverenitet, og oppstiller et medlemskapsprinsipp som skal sikre Norge andel i den kollektiviserte myndighetens utøvelse, er grunnlaget for gjennomskjæring et helt annet. Sammenholdt med medlemskapsprinsippet innebærer Norges avtaler med EU en egentlig omgåelse av grunnlovens regel, formål og intensjon. At Norge kan trekke seg fra samarbeidet, blir fra denne innfallsvinkelen irrelevant og uten betydning. Poenget er i stedet at så lenge avtalene skal bestå - hvilket Norge, EU og avtalene som sådanne forutsetter - så forutsetter man også det tilsynelatende grunnlovsstridige: at Norge skal være «medlem uten å være medlem». Dette er det konstitusjonelle spørsmålet som burde vært drøftet forut for norsk tilslutning.

88. Se f.eks. Andenæs, Dok. nr. 3 (1961-62) s. 11 og Opsahl (1969), s. 508: «Noen vil nok gjerne føye et eller annet til, selv om de er enige i dette, nemlig f.eks. at summen av annen myndighet som overlates, ikke må bli for stor. Men myndighet lar seg ikke måle i prosent...» 


\section{Konklusjoner og perspektiver}

9.1 Medlemskapsprinsippet - et uttrykk for folkesuverenitetsprinsippet

Avsnitt 6 foran viste at vedtakelsen av grunnloven $\$ 115$ hvilte på et premiss om at utenrikskompetansen i grunnloven $\$ 26$ ikke kan delegeres. Det betyr at Stortinget ikke fritt og uten videre kan overføre myndigheten til å fatte beslutninger som er folkerettslig bindende for Norge. Avsnitt 7 foran viste at grunnloven oppstiller en forutsetning om deltakelse - prinsippet om medlemskap - dersom Norge skal overføre slik myndighet til internasjonale organisasjoner. Samtidig som vår grunnlov er svært liberal når det gjelder myndighetsoverføring i forbindelse med internasjonalt samarbeid, forutsetter den at dette skjer som ledd i kollektivisering av suverenitet - slik at man bytter fullkommen selvstendighet mot en andel i kollektivets myndighetsutøvelse. Dette gjelder så vel ved overføring av intern myndighet som ved overføring av myndighet til å binde Norge folkerettslig.

Konklusjonene foran bidrar til å bekrefte artikkelens overordnede tese: Når det gjelder overføring av myndighet, går grunnlovens viktigste skillelinje ikke mellom myndighet av henholdsvis folkerettslig eller internrettslig karakter. Det avgjørende er om Norge er medlem av organisasjonen som myndigheten blir overført til.

I kontrast til artikkelens konklusjoner hviler dagens konstitusjonelle praksis på en skarp sondring mellom overføring av folkerettslig myndighet på den ene side og overføring av intern myndighet på den annen. Verken grunnlovens ordlyd eller øvrige kilder gir belegg for å anse dette som en avgjørende skillelinje. Forarbeidene til grunnloven $\$ 115$ viser tvert imot at bestemmelsen var et oppgjør med en så vidt primitiv tilnærming til spørsmålet om nasjonal suverenitet. Likevel har forståelser av grunnloven $₫ 1$, som synes å være utdaterte, fortsatt å prege norsk konstitusjonell diskurs. Enkelt sagt, dette er feil suverenitet. At Norge som stat har beholdt sin selvstendighet, på tross av landets integrasjon med EU gjennom EØS-samarbeidet og andre avtaler, er det ingen tvil om. Primært handler medlemskapsprinsippet om en annen suverenitet - folkesuvereniteten, slik den kommer til uttrykk i grunnloven $₫ 49$ om lovgivningskompetansen og i grunnloven $\$ 26$ andre ledd om utenrikskompetansen. ${ }^{89}$ Demokratiet er en prosess, det handler om deltakelse. Medlemskapsprinsippet utgjør vår grunnlovs fortsatte vern om denne prosessen, når vårt land og dets folk søker venner $\mathrm{i}$ en stadig mer integrert verden.

89. Om den viktige forskjellen mellom statssuverenitet og folkesuverenitet - en distinksjon som neppe er godt forstått i norsk konstitusjonell rettsteori, se Erik Oddvar Eriksen, «Folkestyrets vanmakt eller en selvbeskadiget demokratisk prosedyre?», i Erik Oddvar Eriksen \& John Erik Fossum, Det norske paradoks, Universitetsforlaget 2014, s. 23-41. 


\subsection{Medlemskapsprinsippet og Norges avtaler med EU}

Når det gjelder Norges forhold til EU, kan grunnlovens medlemskapsprinsipp ha betydning på tre nivåer.

For det første kan medlemskapsprinsippet utgjøre en umiddelbar skranke for norsk tilslutning til bestemte former for internasjonalt samarbeid. La oss for eksempel anta at EU og USA realiserer planen om å etablere en svært omfattende bilateral handelsavtale («The Transatlantic Trade and Investment Partnership TTIP»). La oss videre tenke oss at Norge skulle ønske å slutte seg til denne avtalen, via EU - etter mønster fra Open Skies-avtalen, slik jeg beskrev innretningen av denne i avsnitt 2.1 foran. En slik tenkt konstruksjon ville innebære at Norge får status som om vi er medlem i EU - og at EUs organer skal representere Norges interesser overfor USA i spørsmål om utformingen og innhold av folkerettslige forpliktelser. Fremstillingen har vist at man ikke kan forsvare slik overføring av myndighet til en organisasjon hvor vi ikke er medlem med henvisning til at den «bare» er av folkerettslig karakter. I stedet må tilslutningsformen sammenholdes med grunnlovens medlemskapsprinsipp. For egen del vil jeg anta at TTIP berører så mange sensitive områder, og går så bredt og dypt, at det å kopiere Open Skiesløsningen for TTIPs vedkommende vil være i strid med grunnloven.

For det andre vil medlemskapsprinsippet være en viktig referanse for å vurdere grunnlovsmessigheten av avtaler som formelt ikke overfører at myndighet, slik som EØS-avtalen og Schengen-samarbeidet. Reelt tvinger avtalene frem en meget omfattende resepsjon av europeisk rett. Vi har sett at avtalenes realitetseffekter reiser spørsmål om gjennomskjæring. Bevissthet om grunnlovens medlemskapsprinsipp stiller spørsmålet om gjennomskjæring i et nytt lys. Forutsetningen som avtalene hviler på, om at Norge skal oppnå status som «medlem uten å være medlem», er konstitusjonelt tvilsom.

For det tredje er Norges relasjon med EU blitt så dyp, bred, særegen og konstitusjonelt problematisk at det kan være behov for en egen EU(EØS)-paragraf i grunnloven. Avtaler som allerede er inngått, kan man nok forsvare konstitusjonelt, på ulike måter. For eksempel er det neppe grunn til å utlegge medlemskapsprinsippet helt bokstavelig og absolutt. Forstått som et demokratiprinsipp er det mer for en standard å regne. Man må også akseptere at dersom avtaler som EØS og Schengen i sin tid krenket medlemskapsprinsippet, eller dets intensjoner, må de likevel anses som gyldige i dag, som en form for festnet praksis. Utover å anerkjenne avtalenes egen gyldighet er det imidlertid usikkert hvilken betydning de bør tillegges som tolkningsfaktor. Norges relasjon til EU er spesiell, og det vil være svært betenkelig om praksis på dette området blir tatt til inntekt for at grunnlovens medlemskapsprinsipp er blitt uthulet eller eliminert mer generelt, med 
konsekvenser i andre sammenhenger. Også ved utvidelser av samarbeidet med EU kan det oppstå legitimitetsproblemer dersom dette samarbeidets grunnlag er en selvrefererende praksis, som dypest sett innebærer en tilsidesettelse av medlemskapsprinsippet og dets intensjoner.

\subsection{Medlemskapsprinsippet, grunnloven og demokratiet}

Å peke på at Norges forhold til Europa representerer et demokratisk problem, er, som Europautredningen uttrykker det, «gammalt nytt». Utredningen gir også uttrykk for at de demokratiske problemene har økt de senere år - men sier samtidig at avtalene med EU er «konstitusjonelt trygt forankret». ${ }^{90}$ Utredningens implisitte påstand er dermed at vår grunnlov ikke oppstiller bestemmelser eller prinsipper til vern av demokratiet. Utredningen tar altså ikke avstand fra påstanden om at EØS utfordrer folkestyret, men den sier at dette kun er en politisk ytring, at slike observasjoner er uten rettslig relevans.

Gjennom denne artikkelen har jeg forsøkt å vise det motsatte. Mange av observasjonene er nyskapende, og vil for noen fremstå som provoserende og kontraintuitive. Men egentlig, hvis man legger sine kjepphester til side, vil man se at jeg knappest gjør annet enn å slå inn åpne dører. Til forskjell fra dagens konstitusjonelle doktrine er medlemskapsprinsippet og betraktningen om kollektivisering av suverenitet enkel å begrunne, forankre, praktisere og forstå. Intet er mer opplagt enn at vår grunnlov åpner for internasjonalt samarbeid. $O g$ at den beskytter demokratiet.

\section{Litteraturliste}

Backer, Inge Lorange, «Er Norge fortsatt en selvstendig stat?» i Rettsteori og rettsliv: Festskrift til Carsten Smith, Oslo 2002, s. 43-58.

Bekkedal, Tarjei, Frihet, likhet og fellesskap, Bergen 2008.

Brautaset, Are, «Behov for bilaterale investeringsavtaler», Lov og Rett 2012, s. 385-386.

Castberg, Frede, Norges Statsforfatning, 2. utgave, Oslo 1947.

Colban, Erik, Stortinget og utenrikspolitikken, Oslo 1961.

Eckhoff, Torstein, «EF og Grunnloven», Jussens Venner 1990, s. 196-210.

Eriksen, Erik Oddvar, «Folkestyrets vanmakt eller en selvbeskadiget demokratisk prosedyre?», i Eriksen, Erik Oddvar og Fossum, John Erik, Det norske paradoks, Universitetsforlaget 2014, s. 23-41.

Fleischer, Carl August, «Grunnloven §93», Jussens Venner 1963, s. 73-111.

Fleischer, Carl August, Folkerett, 8. utgave, Oslo 2005.

Gjelsvik, Nikolaus, Lorebok i folkerett, Oslo 1915.

90. NOU 2012: 2 Europautredningen s. $854-855$. 
Hiorthøy, Finn, «Grunnloven og forholdet til utlandet», Nordisk administrativt tidsskrift 1952, s. 12-33.

Holmøyvik, Eirik, «Grunnlova $\$ 93$ og læra om «lite inngripende» myndigheitsoverføring i lys av nyare konstitusjonell praksis», Lov og Rett 2011, s. 447-471.

Høgberg, Benedicte Moltumyr, «EØS-rettens betydning for norsk statsrett», Jussens Venner 2008, s. 159-178.

Lilleby, Fredrik Lied, Grunnloven $\$ 93$ og unntaket for «lite inngripende» myndighetsoverføring, Perspektiv 03/10 (Stortingets utredningsseksjon).

Opsahl, Torkel, «Selvstendighet og kongedømme», Tidsskrift for Rettsvitenskap 1969, s. 490-510.

Pescatore, Pierre, «The doctrine of direct effect: an infant disease of Community Law», European Law Review 1983, s.155-177.

Ross, Alf, Lorebog i Folkeret, 6 udgave, København 1984.

Sejersted, Fredrik, «Læren om 'lite inngripende' myndighetsoverføring - statsrettslig selvbedrag eller fornuftig grunnlovstolking?» Nytt Norsk Tidsskrift 2013, s. 416-422.

Sejersted, Fredrik og Boe, Erik, Schengen og Grunnloven, Oslo 1999.

Smith, Eivind, Konstitusjonelt demokrati, 3. utgave, Bergen 2015, s. 164.

Starke, Joseph G., «Monism and dualism in the theory of international law», British Yearbook of International Law, 1936, s. 66-81.

Triepel, Heinrich, Völkerrecht und Landesrecht, Leipzig 1899

Tverberg, Arnulf, Staten - herre i eget hus? Grunnloven og verden rundt oss, 2015, Lovdata.no 